Eva Liljeblom and Mika Vaihekoski

\title{
OWNERS’ WAY OR THE HIGHWAY: \\ SHORT-TERM EXPECTATIONS AND OWNER IMPATIENCE
}

Forskningsrapporter från Svenska handelshögskolan

Swedish School of Economics and Business Administration

Research Reports

62

Helsingfors 2007 
Owners' Way or the Highway: Short-Term Expectations and Owner Impatience

Key words: impatience, short-termism, investment, compensation, share repurchases, ownership, Finland

(C) Swedish School of Economics and Business Administration \&

Eva Liljeblom and Mika Vaihekoski

Distributor:

Library

Swedish School of Economics and Business Administration

P.O.Box 479

00101 Helsinki, Finland

Telephone: +358-(0)9-4313 3376, +358-(0)9-4313 3265

Fax: +358-(0)9-4313 3425

E-mail:publ@hanken.fi

http://www.hanken.fi/

Edita Prima Ltd, Helsingfors 2007

ISBN 978-951-555-947-0 (printed)

ISBN 978 951-555-948-7 (PDF)

ISSN 0357-5764 


\title{
OWNERS' WAY OR THE HIGHWAY: SHORT-TERM EXPECTATIONS AND OWNER IMPATIENCE
}

\author{
Eva Liljeblom and Mika Vaihekoski ${ }^{*}$
}

February 20, 2007

Comments are welcome.

\begin{abstract}
Increased media exposure to layoffs and corporate quarterly financial reporting have created arguable a common perception - especially favored by the media itself - that the companies have been forced to improve their financial performance from quarter to quarter. Academically the relevant question is whether the companies themselves feel that they are exposed to short-term pressure to perform even if it means that they have to compromise company's long-term future. This paper studies this issue using results from a survey conducted among the 500 largest companies in Finland. The results show that companies in general feel moderate short-term pressure, with reasonable dispersion across firms. There seems to be a link between the degree of pressure felt, and the firm's ownership structure, i.e. we find support for the existence of short-term versus long-term owners. We also find significant ownership related differences, in line with expectations, in how such short-term pressure is reflected in actual decision variables such as the investment criteria used.
\end{abstract}
KEYWORDS: impatience, short-termism, investment, compensation, share repurchases, ownership, Finland

JEL Classification: G31, G34, L21, M51, M52

EFM Classification: $\quad 110,150,220$

\footnotetext{
In alphabetical order. Liljeblom: HANKEN, Swedish School of Economics and Business Administration, Department of Finance. E-mail: eva.liljeblom@hanken.fi, tel. +358 94313 3291, fax +358 943133291. Vaihekoski: Lappeenranta University of Technology, School of Business. E-mail: mika.vaihekoski@lut.fi, tel. +358 5621 7270, fax +358 5621 7299. Latest version of the paper can be downloaded from http://www.lut.fi/ vaihekos/. We thank Markku Kaustia for very helpful suggestions. We are also grateful for the Joint Finance Seminar participants. Authors wish to thank Kenneth Johansson for research assistance. Financial support from Academy of Finland is gratefully acknowledged.
} 


\section{EXECUTIVE SUMMARY IN SWEDISH}

Media har under de senaste åren allt mer bevakat företagens resultatrapportering. En delorsak till detta är säkerligen det att allt fler bolag har övergått till kvartalsrapportering. $\AA$ andra sidan har nyhetsmedierna även gett mycket utrymme åt nyheter om uppsägningar, speciellt i situationer där företagen gått med vinst. På basen av detta har speciellt nyhetsmedierna själva upprätthållit påståendet om att företagen fallit offer för kvartalsekonomin. Med detta har man syftat till ett läge där företagens ägare av dem kräver ständiga resultatförbättringar, även på bekostnad av deras långsiktiga utveckling. Speciellt i samband med resultatrapporteringen har nyhetsmedierna ofta högljutt undrat hur företagets aktiekurs kan reagera negativt även om företaget gör sitt hittills allra bästa resultat. En som inte är så insatt i hur marknadspriserna reflekterar marknadens förväntningar kan utifrån sådana reaktioner lätt få intrycket att ingenting tycks räcka till för aktiemarknaden.

I akademiska undersökningar har den centrala frågan inte så mycket varit existensen av krav på resultat även på kortare sikt - det är en nödvändig del av marknadsekonomin, och ett visst resultattryck behövs för ständig utveckling - utan frågan om huruvida detta tryck blir så stort att företagen tvingas att kompromissa mellan att visa ett möjligast gott resultat på kort eller längre sikt. I denna undersökning studeras frågeställningen med hjälp av en enkätstudie riktad till de 500 största företagen i Finland.

Undersökningen gjordes i juni 2006. Målgruppen var ekonomichefer i företagen på tidskriften Talouselämäs lista över de 500 största bolagen i Finland år 2005. Vi erhöll 149 svar, mao en svarsprocent på $29,8 \%$, vilket kan anses vara god i förhållande till andra liknande studier. Även om undersökningen inte rapporterar resultat för enskilda företag, erhölls svaren så att de kunde relateras till bolagens ägarstruktur och andra bakgrundsvariabler (ekonomisk information). Företagen klassificerades i sju ägarkategorier (andelslag/ ömsesidiga försäkringsbolag o.dyl., familjebolag, företag ägda av stat- och kommun, helägda dotterbolag, samägda företag (ägda av några, vanligen industriella operatörer), företag ägda av kapitalplacerare, samt listade bolag). Av dessa klassades de tre första under arbetsrubriken "långsiktiga ägare" (LT i rapporten), och resten som mera kortsiktiga ägare (ST).

Resultaten visar att det på företagshåll upplevda trycket på kortsiktiga resultatförbättringar är i medeltal rätt högt. På en skala från 1 (lindrigt tryck) till 5 (starkt tryck) var det erhållna svarsmedeltalet 2,98 (med ett median på 3). Företagets ägartyp var av betydelse: medan medeltalet i ST-gruppen var 3,077, var det i LT-gruppen endast 2,289. Skillnaden är statistiskt signifikant och i linje med förväntningarna. På frågan om källan till det kortsiktiga resultattrycket, erhöll svarsalternativen utländska ägare $(3,463)$ och analytiker $(3,129)$ i medeltal de högsta poängen. Minst press i hela svarsmaterialet upplevdes komma från staten $(1,600)$ och arbetstagarna och deras organisationer $(1,798)$, vilket åter är i linje med förväntningarna.

I enkätundersökningen frågade man även hur företagen besvarar trycket från ägarna och marknaden. Den vanligaste metoden var att ta det i beaktande vid fastställandet av avkastningskravet för investeringarna. De därnäst vanliga metoderna var att ta det i beaktande vid utformningen av företagets kompensationssystem och ekonomiska rapportering, medan det var minst vanligt att reagera med ändringar i FoU-investeringarna. 
Horisonten för kompensationsprogrammen visade sig även vara rätt så korta; i de flesta företagen fastställdes resultatlönen närmast på basen av resultatutfallet för en tidsperiod på ett år, om och $7,14 \%$ av de mera långsiktiga företagen (företagen i LT-gruppen) även använde sig av kompensationsprogram med en tidshorisont på över 3 år (det motsvarande antalet sådana användare i ST-gruppen var 2,88\%).

En förvånansvärt stor del av företagen (nästan 40\%) hade försökt inverka på sin ägarstruktur. En delorsak till detta kan vara en strävan till att attrahera mera långsiktiga ägare, som kunde lätta på resultattrycket. De vanligaste metoderna var dividendpolitiken, ägarträffarna, och företagets marknadskommunikation.

Återköp av egna aktier hade någon gång företagits av $27 \%$ av företagen. De vanligaste orsakerna angavs vara utvecklandet av ägarstrukturen, utvecklandet av kapitalstrukturen, samt det att aktien var undervärderad. Endast två företag valde som ett svarsalternativ beskattningsrelaterade orsaker, vilket speciellt den akademiska finanslitteraturen ofta lyfter fram som en huvudorsak till återköp av egna aktier.

Endast 9,1\% av företagens FoU-investeringar angavs vara riktade till projekt, av vilka man inte väntar sig ett vinster under de närmaste fem åren. Andelen är förvånansvärt låg i jämförelse med resultaten från USA $(22,6 \%)$ och Sverige $(25,4 \%)$. När man frågade den hypotetiska frågan om hur mycket mera företagen skulle investera, om de vore rätt värderade, erhöll man medeltalet $9,96 \%$, som är något högre än det man erhöll i Sverige $(5,8 \%)$, men å andra sidan lägre än resultatet från USA $(20,7 \%)$.

Slutligen frågade man efter det i genomsnitt tillämpade avkastningskravet för investeringar, och återbetalningstiden. Som svar erhöll man i medeltal 5,009 år för återbetalningstiden, och 15,485\% för avkastningskravet. Avkastningskravet är förvånansvärt högt, eftersom med dagens ränteläge och de vanliga riskpremieförväntningarna, skulle finansieringsteorin förespråka ett avkastningskrav klart under 10\% för de flesta företagen. Avkastningskravet är även förvånansvärt stabilt, och verkar inte ha beaktat den klara nedgången i räntenivån som skett sedan tidigare studier (Liljeblom och Vaihekoski, 2004, och Keloharju och Puttonen, 1995) som rapporterade snarlika resultat.

Spridningen i svaren på frågan om avkastningskravet var i linje med förväntningarna gällande ST- och LT-grupperna. Det högsta svarsmedeltalet gavs av kapitalplacerarna $(25,136 \%)$. De listade bolagen kom som tvåa (16,962\%), med ett högt värde trots att ägarna för dessa bolag kan diversifiera sina placeringar. Det lägsta avkastningskravet gavs av gruppen stats- och kommunägda företag $(9,833 \%)$.

Sammanfattningsvis kan man konstatera att Finlands största företag verkar i medeltal uppleva ett relativt stort tryck på att förbättra sina resultat på kort sikt. De ägargrupper som bildades på basen av förhandsförväntningarna verkar i många fall signifikant förklara skillnader mellan svaren, något som stöder hypotesen om att ägarens typ har betydelse. Det återstår dock att undersöka huruvida dessa skillnader även reflekteras i företagens realiserade lönsamhet, och värdering. 


\section{EXECUTIVE SUMMARY IN FINNISH}

Media on alkanut viimeisten vuosien aikana yhä enemmän seurata yritysten tulosraportointia. Osasyynä on varmasti se, että yhä useampi yritys on siirtynyt neljännesvuosiraportointiin. Toisaalta mediassa on annettu paljon tilaa myös yritysten irtisanomisuutisille erityisesti tilanteissa, joissa yritys tekee voittoa. Tämän perusteella erityisesti media itse on pitänyt yllä väitettä, että yritykset ovat joutuneet kvartaalitalouden uhreiksi. Tällä on yleisesti tarkoitettu tilannetta, jossa omistajat vaativat yrityksiltä jatkuvaa tulosparannusta jopa pitkän aikavälin kehityksen kustannuksella. Erityisesti tulosjulkaisujen yhteydessä media usein suureen ääneen ihmettelee, miten yhtiön osakekurssi voi reagoida negatiivisesti vaikka yritys tekisi historiansa parhaan tuloksen.

Akateemisessa tutkimuksessa keskeisenä kysymyksenä ei ole lyhyen tähtäimen paine - se on välttämätön osa markkinataloutta ja toiminnan kehittämistä - vaan se, että tämä paine kasvaa niin suureksi, että sen seurauksena yritys joutuu tinkimään toimintansa pitkän aikavälin oikean suuntaisesta kehittämisestä. Tässä tutkimuksessa tarkastellaan tätä kysymystä Suomen 500 suurimmissa yrityksessä tehdyn kyselyn tulosten avulla.

Kysely tehtiin kesäkuussa 2006 yritysten talousjohtajille. Vastauksia saatiin 149 ja vastausprosentti oli $29,8 \%$, jota voidaan pitää hyvänä muihin tutkimuksiin verrattuna. Vastaukset saatiin nimettömänä, mutta kuitenkin niin, että tutkimuksen tekijät pystyivät identifioimaan yritykset. Yritysten vastaukset yhdistettiin yritysten omistajatietoon sekä taloudelliseen informaatioon. Yritykset luokiteltiin omistajataustansa perusteella seitsemään ryhmään (osuuskunnat/keskinäiset vakuutusyhtiöt, perheyritykset, valtio- ja kuntaomisteiset yritykset, $100 \%$ tytäryhtiöt, yhteisyritykset, pääomasijoittajien omistamat sekä julkisesti listatut yritykset). Näistä kolme ensimmäistä luokiteltiin vielä pitkäaikaisiksi omistajiksi (raportissa LT) ja loput neljä lyhytaikaisemmiksi omistajiksi (ST).

Tulokset osoittavat, että yritykset tuntevat keskimäärin suhteellisen vahvaa lyhyen tähtäimen painetta. Asteikolla 1 (lievä paine) - 5 (voimakas paine) vastausten keskiarvo oli 2,98 (mediaani 3). Yritysten omistustaustalla on merkitystä vastausten kannalta. STryhmään kuuluvien yritysten keskiarvo oli 3,077 ja LT-ryhmään 2,289. Ero on tilastollisesti merkittävä ja odotusten mukainen. Kysyttäessä lyhyen tähtäimen paineiden aiheuttajaa, korkeimman tuloksen saivat ulkomaalaiset omistajat $(3,463)$ ja analyytikot $(3,129)$. Vähiten painetta aiheuttavat valtio omistajana $(1,600)$ ja työntekijät sekä heidän työntekijäliittonsa $(1,798)$, mikä on edelleen odotusten mukaista.

Yritysten yleisin menetelmä lyhyen aikavälin paineisiin vastaamisessa on investointien tuottovaatimuksen muuttaminen. Seuraavaksi suosituimpia menetelmiä olivat palkitsemisjärjestelmän suunnittelu sekä taloudellinen raportointi. Vähiten tilanteeseen oli reagoitu T\&K-menojen vähentämisen kautta.

Kysyttäessä yritysjohdon palkitsemisjärjestelmän horisonttia ts. miltä ajalta lasketaan johdon tulospalkkaan vaikuttava tulos. Valtaosalla yrityksissä ne perustuivat yhden vuoden tuloksellisuuteen, joskin pitkäaikaisomistajien (LT) omistamissa yrityksissä 7,14\% tapauksista käytetään yli kolmen vuoden horisonttia (vrt. 2,88\% ST-ryhmässä).

Yrityksistä yllättävän suuri osa, miltei $40 \%$, oli pyrkinyt vaikuttamaan omistusrakenteeseensa. Osin tämän taustalla voi olla pyrkimys pitempiaikaisempiin 
omistajiin, joka voisi lievittää omistajien lyhyen tähtäimen painetta yritysjohdolle. Suosituimmat keinot olivat osinkopolitiikka, sijoittajatapaamiset ja yrityksen viestintä.

Yrityksistä noin $27 \%$ oli ainakin joskus ostanut osakkeitaan takaisin. Suosituimpia syitä takaisinostoille oli yrityksen omistusrakenteen kehittäminen, yrityksen pääomarakenteen kehittäminen sekä osakkeen aliarvostus. Vain kaksi yritystä valitsi syyksi verosyyt, jonka erityisesti akateeminen kirjallisuus nostaa usein takaisinostojen pääsyyksi.

Yrityksien T\&K-investoinneista vain 9,1 \% on suunnattu projekteihin, joista ei odoteta tulos lähimmän viiden vuoden sisällä. Luku on yllättävän matala verrattua USA:sta ja Ruotsista saatuihin tuloksiin nähden (USA: 22,6 \%, Ruotsi: 25,4 \%). Kysyttäessä kuinka paljon yrityksen lisäisivät investointejaan, jos yritys arvostettaisiin oikein, keskiarvoksi saatiin 9,96\%, joka on hieman Ruotsin lukua korkeampi $(5,8 \%)$, mutta toisaalta USA:n tuloksia matalampi $(20,7 \%)$.

Lopuksi yrityksiltä kysyttiin investointien tuottovaatimusta ja takaisinmaksuaikaa. Keskimääräinen takaisinmaksuaika oli 5,009 ja tuottovaatimus 15,485\%. Tuottovaatimus on yllättävän korkea, koska rahoitusteorian perusteella laskettu tuottovaatimus olisi useimmille yrityksille selkeästi alle kymmenen prosenttia. Tuottovaatimus on myös yllättävän vakaa eikä tunnu huomioivan korkotason selkeää muutosta, sillä aikaisemmat tutkimukset (Liljeblom ja Vaihekoski, 2004 sekä Keloharju ja Puttonen, 1995) raportoivat miltei identtisiä tuloksia.

Tuottovaatimusta tarkasteltaessa, korkein tuottovaatimus on selkeästi ja odotetusti pääomasijoittajille $(25,136 \%)$. Toiseksi korkein tuottovaatimus on pörssiyrityksillä $(16,962 \%)$, jota voidaan pitää erityisen yllättävänä, onhan niiden omistajilla mahdollisuus hajauttaa omistuksensa helposti alentaen oman pääoman tuottovaatimusta. Matalin tuottovaatimus on odotetusti valtio- ja kuntaomisteisilla yrityksillä $(9,833 \%)$.

Yhteenvetona voidaan todeta että Suomen suurimmat yritykset keskimäärin näyttivät kokevan kohtalaisen vahvaa lyhyen tähtäimen painetta. Ennakko-odotusten pohjalta luodut omistajakategoriat näyttivät monien muuttujien suhteen selittävän eroja vastausryhmien välillä, antaen tukea sille että omistajuudella on merkitystä, ainakin yritysten kokemien tulospaineiden suhteen. Selvitettäväksi jää miten erot myös heijastuvat yrityksien toteutuvaan kannattavuuteen, ja arvostukseen. 


\section{CONTENTS}

1 INTRODUCTION

2 PREVIOUS RESEARCH AND HYPOTHESES DEVELOPMENT ..................12

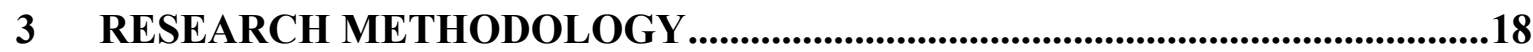

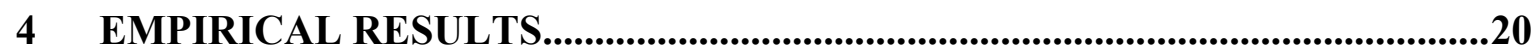

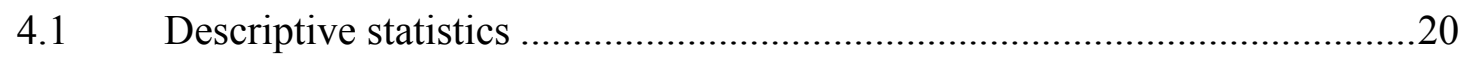

4.2 Perceived financial short-term pressure ..................................................21

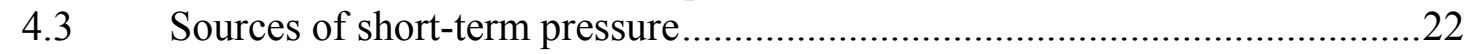

4.4 Actions taken to alleviate the short-term pressure .......................................24

4.5 Horizon of the management compensation scheme .....................................26

4.6 Performance criteria for the management compensation scheme..................27

4.7 Active company ownership structure management .....................................29

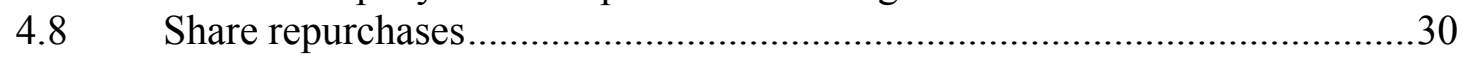

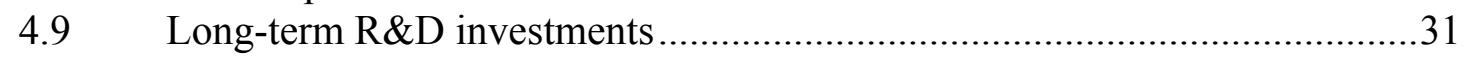

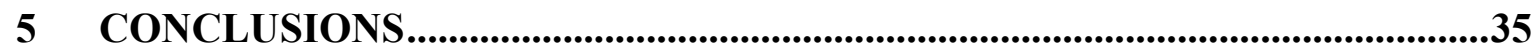

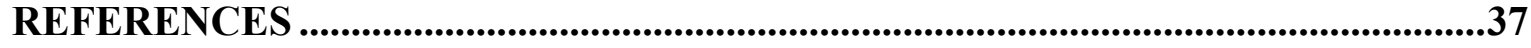

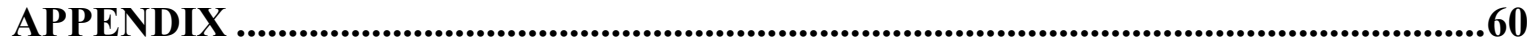




\section{INTRODUCTION}

The importance of institutional owners has increased considerably over the last years. ${ }^{1}$ Institutional owners, such as pension funds and mutual funds, share many characteristics that set them apart from individual investors. They often have strict guidelines for the portfolio weights for individuals stocks, bias their portfolios towards highly liquid stocks ${ }^{2}$, and tend to rather vote with their feet (sell off their shares) than try to influence corporate strategy through proxy voting at the annual general meeting. It has often been suggested that such behavior leads to managerial myopia, i.e. shortsighted corporate decision making. Fragmented evidence of owner myopia has also been produced in several studies. Earlier research findings indicate that frequent trading and short-term focus of institutional investors may (1) encourage managers to sacrifice long-term investments such as R\&D to meet current earnings targets (Bushee 1998), lead to (2) dividend avoidance / a preference for share repurchases (Gaspar et al. 2005a), (3) excess volatility (Sias 1996, Bushee and Noe 2000), and a weaker bargaining power in corporate acquisitions (Gaspar et al. 2005b). Finally, shortsighted investment behavior can weaken governance mechanisms of a firm and thereby lead to e.g. higher levels of managerial compensation (Clay 2000). Whereas these results are typically obtained using U.S. data, Segelod (2000) finds in a survey of Swedish firms, support for much less pressure for short-term behavior as compared to the U.S.

Contrary to the earlier studies, focusing on one consequence of owner myopia at a time, and separating between institutional and other owners, we study both the origins of such short-term pressure, and its consequences with respect to several corporate decisions, in a sample of firms with several different forms of ownership. We combine three sources of data: (1) survey data on perceived pressure for short-term decisions, and corporate reactions to it, (2) financial data on actual firm characteristics and performance, and (3)

1 For example, Gompers and Metrick (2001) document that institutional investors have nearly doubled their holdings in U.S. stocks since 1980. Puttonen (2004) reports, that in Finland the domestic household investors' share of the market capitalization has decreased from about $40 \%$ in 1985 to less than $20 \%$ today.

2 For the determinants of such portfolio investments, see e.g. Dahlquist and Robertson (2001), and Liljeblom and Löflund (2005). 
data on detailed ownership structures. Our data set is the respondents (149 firms) in a survey, directed the 500 largest companies in Finland conducted in June 2006. ${ }^{3}$

We contribute to the previous literature in several ways. First, we report combined results on both perceptions as well as actions. Second, we study multiple different corporate decisions in a much richer ownership setting as is customary, since our data set includes both widely held stock listed companies, foreign subsidiaries, state and municipality owned firms, as well as firms owned by their customers such as mutual insurance companies and co-operatives. Third, to the body of literature on U.S. markets, we bring some complementing evidence from a small Nordic country, which may have experienced the pressures for short-term behavior with a lag and hence may show more variation in the results. Finally, some of the questions studied are ones on which there is little prior evidence, such as the question of the various sources, also the ones related to media and society and not the owners themselves, of perceived pressure for short-term behavior.

We find that companies in general feel moderate short-term pressure, with reasonable dispersion across firms. We analyze the effect of ownership on pressure felt, both using seven different ownership types, as well as only two broader groups: short-term and longterm owners. There are significant links between the degree of pressure felt, and the firm's ownership structure, i.e. we find support for the existence of shorter and long-term owners. We also find significant ownership related differences, in line with expectations, in how such short-term pressure is reflected in actual decision variables of the firm. When it comes to adjusting to pressure, the most active ones are firms owned by private equity investors, whereas co-operatives feel the lowest need to do so. The decision most affected by shortterm pressure seems to be the choice of the rate of return required in investment decisions. For this decision variable, there is a significant difference between the averages used by short-term firm (17.1 per cent) versus long-term firms (12.8 per cent).

The remainder of this paper proceeds as follows. In section 2, we discuss the related literature in more detail as well as develop testable hypotheses. The research design and methodology is presented in section 3 . Section 4 presents the main empirical results

3 The 500 largest firms were selected on the basis of their turnover in 2005. These firms are annually analyzed by Talouselämä, a leading Finnish financial weekly magazine. 
together with discussion of their implications. The final section concludes and offers some suggestions for further research. 


\section{PREVIOUS RESEARCH AND HYPOTHESES DEVELOPMENT}

When investigating the relationship between short-term owners and corporate behavior, it is crucial to know which owner categories can be viewed as short-term ones. In prior literature, researchers have often studied the effects of institutional owners versus others. However, as noted by Gaspar et al. (2005b), institutional ownership is a mixed category as such, and may include both short-term mutual funds as well as long-term owners. ${ }^{4}$ Not surprisingly, there are two contrary views of the nature of institutional ownership. One view posits that a higher degree of institutional ownership leads to more efficient monitoring, and therefore to better governance (see e.g. Dobrzynski 1993, Monks and Minow 1995). The other view maintains that institutional ownership can also have several disadvantages such as a higher probability to manipulate earnings and preference for shortterm projects.

When looking at institutional ownership as such, conflicting evidence of their monitoring ability has been detected. For example, Clay (2002) found evidence of higher salary levels, but also higher performance-to-pay sensitivities in firms with high institutional ownership, whereas Hartzell and Starks (2003) found that institutional ownership was positively associated to performance-to-pay sensitivities but negatively to the level of compensation. Similarly, whereas Sias (1996) found a positive relationship between institutional ownership and stock volatility, Bushee and Noe (2000) found that while higher disclosure firms had higher institutional ownership, the particular type of institutional investor attracted to greater disclosure had no net impact on volatility. However, when controlling for the trading behavior of the investor, increasing ownership by more 'transient' institutions seem to be followed by increases in stock return volatility.

Therefore, more recent studies have often used more sophisticated measures for investor short-termism than just the investor type. Using cluster analysis, Bushee (1998) developed a method to classify institutional investors into shorter and longer-term investors based on characteristics of their portfolio such as its concentration and turnover, and the trading

4 Moreover, the horizon of certain investor types can change over time. Bogle (2003) reports that mutual funds in the U.S. were around 2003 holding a stock in their portfolio for an average holding period of roughly a year, whereas the average holding period was six years in the early seventies. 
sensitivity to current earnings. Using an indicator for short-termism, he found that high turnover and momentum trading by institutional investors encourages myopic investment behavior (lower corporate R\&D investments) when such investors have extremely high ownership levels in a firm. Otherwise, institutional ownership rather reduces the pressures on managers' myopic investment behavior.

Later, the method of Bushee has been used in several studies of short-term behavior such as in the Bushee and Noe (2000) study of institutional ownership and volatility. Using the Bushee (1998) methodology, Dikolli et al. (2003) found that when investor horizons are short, the contracting weight of returns in executive compensation is positively associated with CEO horizon. This means that forward-looking measures are used in contracting to overcome the potential negative long-term effects of a misalignment of interests, when the CEO's and investors' horizons differ.

Other ways to identify 'transient' investors is to use either more straightforward portfolio turnover measures, or measures of holding periods. Using data on the turnover of the institutional investors' asset portfolios, Gaspar et al. (2005a) found that US short-term institutional investors have a higher propensity to buybacks i.e. a preference for them instead of cash dividends. Similar method was also used in Gaspar et al. (2005b). They found that target firms with short-term shareholders are more likely to receive an acquisition bid but get lower premiums, i.e. they have a weaker bargaining power in corporate acquisitions.

Holding period measures were in turn used by Bøhren et al. (2004), who studied ownership duration on the Norwegian market. They found e.g. that financial institutions and foreign owners had the shortest ownership durations, while industrial companies and the state stayed the longest. They actually found that firm performance generally decreased as ownership duration increased, but the results were sensitive to the type of owner. Whereas long-term ownership by financial institutions and industrial owners tended to hurt firm performance, the opposite was true for private ownership. Also controlling for the length of the holding period, Chen et al. (2005) in turn found evidence on institutional investor monitoring in acquisition decisions being value enhancing only when large stakes were held by a long-term or independent institutional investor. 
Whereas these results are typically obtained using U.S. data, Segelod (2000) finds in a survey of Swedish firms, support for much less pressure for short-term behavior as compared to the U.S.

In this paper, we will first study the degree to which companies owned by different investor categories perceive that they are pressed to constantly, in the short-term, report increasingly good results. Using categories somewhat similar to those in Bøhren et al. (2004), we classify the firms into seven categories based on their ownership structure: fully-owned subsidiaries, co-operatives and other firms owned by their owners such as mutual insurance companies, state or municipality owned firms, family firms, firms owned by several industrial companies, firms with large private equity owners (controlling more than $40 \%$ of equity), as well as publicly listed firms.

Based on the expected transitory / more permanent nature of the ownership as well as prior research findings, we also divide the firms into firms with potentially more long-term (LT) and short-term (ST) owners. Family ownership is often pointed out as a more patient form of ownership / a type of ownership, which is favorable for the firm in the long term (e.g. Bøhren et al. 2004, Maury and Pajuste 2005). We therefore include family firms in the category of LT firms. Since government owned firms as well as co-operatives are likely to have multiple objectives i.e. objectives other than profit maximization (such as competitive prices in the long-run for the owners), we expect these firms to be less likely to sacrifice long-term goals for short-term profits, and therefore include them as well in the category of LT firms. Their ownership structure is also more permanently defined (the likelihood for corporate takeovers is low or nonexistent in this category), also motivating a lower expected likelihood for short-term pressure in this category. ${ }^{5}$

The category of ST firms will include firms with higher institutional ownership such as private equity firms and listed firms. Private equity investors have typically plans to exit

\footnotetext{
These firms may, however, suffer from corporate governance problems, so their inclusion in the category of LT firms does not in itself mean that they necessarily are expected to perform better. However, since in the first stage of study we are above all investigating perceptions of short-term behavior, not actual expost performance, this classification serves it purpose, since such firms may be expected to experience less pressure from their owners also because of weaker corporate governance.
} 
within a rather short horizon such as within the next 2-3 years. We therefore expect that such firms have a strong focus on short-term restructuring activities and immediate performance improvements. Listed firms, in turn, are subject to short-term pressure due to a high ownership by mainly other types of short-term investors such as mutual funds, and other institutional investors (often foreign ones). We expect that such firms are more likely to forward this pressure also to their associated non-listed companies. We therefore include subsidiaries $^{6}$ as well as firms owned by several industrial firms into the category of ST firms.

Concerning the general perceptions of short-term pressure, we expect these pressures to be higher for ST firms. Since ST firms are more transparent and owned by a larger investor base, we also expect that the sources for the pressure are to a higher degree purely market (well-diversified investor) related sources such as foreign investors and financial analysts. For LT firms, more pressure can be expected from the relevant (often less diversified) investor, and other influential stakeholder categories (political sources as well as media and unions for government owned firms, family for family firms, etc.). Our hypotheses are thus:

\section{Hypothesis 1: ST firms are more subject to short-term pressure than LT firms.}

Hypothesis 2: ST firms are relatively more subject to pressure from market and well diversified investor sources (analysts, Finnish institutional and other owners, foreign owners) whereas LT firms are relatively more subject to pressure from the relevant large investor and other influential stakeholder categories (media, politicians, government, family, workers and their unions).

Next, we analyze the actual actions undertaken because of short-term pressure. We expect that ST owners have in general undertaken more actions as compared to LT owners. Private equity controlled firms may represent one extreme in this sense, since they are likely to be the most exit-oriented in the short-term, and therefore most likely to restructure the firm (pay out excess cash, sell out off-spins, increase the leverage, retain from long-term

\footnotetext{
Many subsidiaries in the Talouselämä 500 list are owned by foreign owners, an owner category observed to be especially short-term oriented e.g. in Bøhren et al. (2004). Foreign subsidiaries are often the first ones to be shut down when firms are consolidating their activities. Therefore, the short-term pressure can be expected to be high in our sample for the subsidiaries.
} 
investments, and more aggressively fire workers). ${ }^{7}$ Another interesting subquestion is the actions undertaken in government-controlled firm. For these firms, layoff decisions may be more difficult, and compensation design more subject to public criticism and therefore more conservative.

Hypothesis 3: ST firms have undertaken more actions to accommodate for shortterm pressure.

Hypothesis 4: Private equity firms are expected to be the most aggressive ones when it comes to accommodate for short-term pressure.

Hypothesis 5: Government and municipally controlled firms are less likely to undertake aggressive layoff or compensation decisions based on pressures for good performance in the short-term.

Finally, we investigate questions relating to the horizon of executive compensation systems, share repurchases, and long-term investments including the discount rate used in the firm. We expect that LT firms use in general more forward-looking systems based on long-term profitability rather than immediate cash flow. We also expect that they are less likely to use share repurchases because of lower tax incentives as well as lower incentives to boost financial report figures (EPS). Finally, we expect that they have better possibilities for active ownership development, and that they have longer investment horizons with potentially lower required rates of return. ${ }^{8}$ Our hypotheses are thus:

Hypothesis 6: LT firms are using management compensation plans with longer horizons, and more focus on long-term profitability and growth, as compared to current valuation or operational cash flow.

\footnotetext{
Our category of "private equity" is rather broad, including many different private equity (venture capital) firms, which of course may differ from each other in their average holding periods and exit strategies. The behavior described above in the text is above all typical to one specific type of private minority investor, sometimes called an "activist owner" (who often operates through an investment company or fund, and attracts private equity investors to joint actions). See e.g. Bethel et al (1998) for corporate actions followed by block share purchases by activists versus other investors.

8 A lower discount rate for LT firms can also be the result of potentially lower risks for these firms, since they may be operating in more protected sectors of the economy. For co-operatives, a lower required return can be the conscious result of a trade-off between higher profitability on one hand, and better offerings e.g. in the form of lower selling prices / higher purchasing prices for the customer- or supplierowners of such firms on the other hand. The co-operatives among the Talouselämä 500 list include mutual insurance companies and banks, co-operative retail chains, as well as agricultural co-operative producers owned by their suppliers.
} 
Hypothesis 7: LT firms are less likely to use share repurchases.

Hypothesis 8: LT firms are more likely to be able to develop actively their ownership structures i.e. the resulting ownership structure is at least partly the result of an active ownership policy.

Hypothesis 9: LT firms have longer investment horizons, longer payback periods and lower discount rates. 


\section{RESEARCH METHODOLOGY}

To study the questions, we decided to conduct a survey using a mailed questionnaire (see Appendix). The questions in the questionnaire focus on three main areas: 1) respondents' opinion (perception) of the short-term financial pressure that the company faces, 2) what actions have the companies done to alleviate these pressures, and 3) questions concerning some actual decisions variables for the company such as payout policy (share repurchases), executive compensation, and investment practices. For comparison to earlier studies and to provide diagnostic variables, we also ask few additional questions concerning the companies' investment practices. To maximize the response rate, the questionnaire was designed to fit on one page only. Similarly, the questions were designed to be easy and fast to answer, with an option to provide additional explanations if the respondent felt that the reply so warranted.

The survey was conducted among the 500 largest companies registered in Finland as listed by the Finnish weekly business magazine Talouselämä in May 2006. Talouselämä ranks companies on the list according to their turnover during year 2005. To make it to the list, the turnover had to be larger than 67 million euros. The largest company on the list was Nokia Corporation with a turnover of 34.2 billion euros.

The questionnaire was sent using the regular mail to companies' financial manager in early June 2006. If the financial manager could not be identified, the questionnaire was sent to the managing director. Respondents were promised total anonymity, i.e., their names or the company cannot be identified from the study although the company and the corresponding response were identifiable. However, this information was kept only to the authors of this study and the responses were recoded before giving the responses to the research assistant.

After the responses were collected into a database, it was matched with hand-collected corresponding information of the respondents' ownership type. Each responding company was given ownership-type category from the following list: 1) co-operative or mutual insurance companies, 2) 100 per cent government-owned companies (includes both state and municipal-owned companies), 3) family-owned companies, 4) 100 per cent owned subsidiaries, 5) companies owned jointly by several industrial and/or financial owners 
(joint companies) ${ }^{9}, 6$ ) companies where at least $40 \%$ of the equity is owned by (one or many) private equity investors (or venture capitalists), and 7) publicly listed companies. ${ }^{10}$

Figure 1 shows the distribution of the companies on the basis of the ownership. Fully owned subsidiaries are most common companies in the sample representing 28.9 per cent of the companies. Publicly listed companies are the second most popular form of ownership in our sample representing 22.8 per cent of the sample. Publicly listed companies are slightly over-represented in our sample as only 16 per cent of the top 500 companies are publicly listed. Companies owned jointly by several firms represent the smallest ownership type in the sample with a presentation of 4.7 per cent of all respondents.

As noted earlier, we group companies into LT and ST categories on the bases of their ownership category. As a result, categories 1-3 are assigned into the long-term focus group (labeled henceforth as LT) and all other ownership categories as short-term owners (ST). LT-category includes 49 companies (32.9\% of all companies), and ST-category 99 companies $(66.4 \%)$. One company could not be assigned to either category. LT and STgroups are used to analyze our hypothesis that companies' ownership and owners' patience has an effect on the results.

Finally, companies are also matched with their financial information to get some kind of insights into how the sample compares with the population. Financial information data is taken from ETLA's financial database for the 500 largest companies. It includes industry classification for all companies and over fifty financial figures for the companies collected from publicly available financial statements for year 2005. In many cases, however, certain financial information is either missing or not applicable.

\footnotetext{
9 Many of these companies are 50\%-50\% owned joint ventures by two industrial firms.

10 Category 5, jointly owned companies, includes a few cases with approximately equal ownership shares by industrial firm(s) on one hand, and the government and / or municipalities on the other hand. Category 1, co-operatives, includes a few cases where the company is not in itself organized as a co-operative, but is owned by a group of owners which are co-operatives, or behave as such (and are e.g. suppliers / customers of the firm).
} 


\section{EMPIRICAL RESULTS}

\subsection{Descriptive statistics}

Descriptive statistics of the full population and our sample (respondents) can be found from Table 1 . We received 149 responses in time for this study. They represent approximately 29.8 per cent of the total sample, and the response rate can be considered to be fairly high for this kind studies. ${ }^{11}$ One of the companies chose not to identify itself and therefore, it is removed from analysis where responses are matched with background information such as ownership.

Panel A reports the distribution of the ranking in the population and in our sample within one hundred company size quintiles. All quintiles represent twenty per cent of the companies in the population. In our sample, the second population size quintile (companies ranked 101-200) has the smallest representation of 18 firms. On the other hand, the maximum representation in our sample is 44 firms from the first population quintile. As a result, the largest one hundred companies may by slightly overrepresented in the sample (30.1 per cent vs. population 20 per cent) and the companies in the second quintile may be slightly underrepresented (12.1 per cent), but overall the populations can be said to be fairly well covered.

Panel B reports the averages of a few key financial statistics for the 500 largest companies as well as our respondents. ${ }^{12}$ The average turnover for the top 500 companies is 591.2 million euros, whereas the average turnover for the companies is the sample is slightly larger, 741.2 million euros. Similarly, companies in the sample invested slightly more during 2005 than the top 500 companies on average (40.2 vs. 32.0 million euros) and they had more employees (2787 vs. 1920), but on the other hand they were slightly less profitable (13.6 vs. 28.4 million euros). The average market value of the responding

11 Poterba and Summers (1995) had a response rate of 22.8 per cent in a similar study among 1000 US companies. Segelod (2000) had a response rate of 45 per cent with a sample of 130 Swedish companies. Graham and Harvey (2001) had a response rate of 9 per cent in their study among largest 500 companies in the USA. Liljeblom and Vaihekoski (2005) had a response rate of 32 per cent with a sample of 144 Finnish publicly listed companies.

12 Note that not all financial items are available for all companies. In some cases, all financial information is missing due to the publication lag. 
publicly listed companies (not reported) was at the end of 2005 slightly more than one billion euros.

\subsection{Perceived financial short-term pressure}

The first question in the questionnaire asked the companies to indicate the degree to which they have experienced financial short-term pressure, a pressure such that it is causing some conflict with the company's long-term goals. Respondents could choose between a value of 1 (very little) through to 5 (very much), or 0 (not relevant for the company).

Panel A of Table 2 reports the results first for the full sample and then for the two subsamples, namely for those companies belonging to the long-term (LT) or the short-term (ST) ownership category. Altogether, we received 148 responses to this question. The great majority of the respondents felt that they have felt at least some short-term pressure even though 18 responses (12.16 per cent) answered that the question is not relevant for them. The average score given by companies who did not choose this question to be irrelevant was in the middle of the scale, i.e. 2.838. The median value of 3 shows that half of the companies experienced medium or higher short-term pressure, i.e. the question of shortterm pressure among Finnish firms is not irrelevant. ${ }^{13}$ This average, together with a reasonable dispersion among the answers, thus offers a good starting point for further analysis.

As expected, the results for the LT and ST categories differ considerably. First, companies belonging to the long-term category were much more likely to answer that this question is not relevant for them (20.83\% vs. $8.03 \%)$. Second, companies belonging to the LT category seem to be experiencing expectedly much lower short-term pressure (average response 2.289 with median value of 2 ) than those in the ST category $(3.077$, median 3$){ }^{14}$ The average values differ statistically significantly from each other when tested using a $t$ -

13 It is well known fact that one should be cautious in calculating the average and standard deviation for a variable measured on an ordinal scale. However, average is commonly used approach in similar studies and it is only used to suggest potential differences in different sub-samples. Similarly, standard deviation is mainly used to show the dispersion in the responses.

14 Note that 148 companies answered this question, but for one of them we could not identify ownership category leaving us with 147 responses for the ownership analysis. 
test for two samples with unequal variances (a t-value of 3.74, significant at the $1 \%$ level). ${ }^{15}$ This also indicates that our grouping of the firms by ownership into ST and LT categories successfully partitions the sample in terms of pressure felt.

Panel B reports the results separately for each one of the seven ownership categories. We expected to see publicly listed, by private equity owned, and joint companies as well as 100 $\%$ owned subsidiaries to show higher than average short-term pressure and respectively cooperatives, government-owned, and family-owned companies to show below average figures. As expected, co-operatives and family-owned companies show the lowest values, whereas listed firms, firms owned by private equity, as well as the subsidiaries show the highest values. Surprisingly, joint-owned companies show relatively low average shortterm pressure, but the sample is small and the dispersion of the responses is high.

\subsection{Sources of short-term pressure}

Next we asked the respondents to indicate how much certain key stakeholders and interested parties are causing short-term pressure. Respondents were given a list of different actors and again they could choose a value between 1 (very little) and 5 (very much), or 0 (not relevant for the company) for each one. In few cases more than one answer were marked (typically a value between one and five and 'not relevant' option). In these cases the answer was excluded from the analysis. The results are reported in Table 3 for each stakeholder separately, first for the full sample and then for LT and ST categories followed by more detailed analysis for each ownership type. Percentage not relevant is the number of answers indicating not relevant divided by the total number of answers $(N)$ for the particular question.

The results in Panel A show that the highest source of short-term pressure comes from the foreign owners (average response 3.463), then from the analysts (average response 3.129). Somewhat surprisingly, the media is not a major reason behind short-term pressure (average response 2.505) even though many people have voiced their concern that the quarterly reporting of the companies in the media is a major reason for the short-term bias

\footnotetext{
15 All later t-tests between means are calculated assuming for two samples with unequal variances.
} 
in the companies' decision-making. ${ }^{16}$ On the other hand, media has the lowest percentage of "not relevant"- answers (14.4 per cent), i.e. few companies consider that the media is not at all guilty of creating short-term pressure.

Expectedly, the government (as an owner) and workers (and their unions) are not found to be major cause behind the short-termism. The average responses for the government and workers are 1.699 and 1.798, respectively. Indeed, it is in the best interest of both these stakeholder groups to advance companies' long-term viability and employment over shortterm profitability even though these interests may not be compatible in all circumstances.

Next, we analyze the sources of pressure separately for the ST and LT firm groups (Table 2, panels B and C). As expected, LT firms are - relative to ST firms - more sensitive to pressure from special influential owner categories such as the government (an average of 2.000 as compared to $1.483, \mathrm{t}$-value of 2.36 for the difference) and family (3.120 vs. 2.435, t-value of 2.28), and less sensitive to external market / diversified investor forces such as analysts (1.950 vs. 3.458, t-value of -3.79), and foreign owners (2.375 vs. 3.616, t-value of -3.01). The results are also in line with our expectations of a higher pressure among LT firms from media (scores of 2.556 and 2.494 for LT and ST firms, respectively), politicians (1.944 vs. 1.818), and the unions (1.952 vs. 1.736), and lower for Finnish institutional owners (2.500 vs. 2.556), although these differences are marginal. Only concerning other Finnish owners, the results are contradictory to our Hypothesis 2, since we get a higher score for this ownership category within the group of LT owners (3.071 vs. 2.847), perhaps because of problems in categorizing owners. ${ }^{17}$

Next we analyze the responses with respect to the owner type. Results are reported in Panels D-L of Table 3. The short-term pressure created by media is found to be the highest for the co-operatives and jointly-owned companies (both with an average response of 3.000). Analysts, on the other hand, are expectedly found to create mostly short-term pressure for publicly listed companies (3.800) and 100 per cent owned subsidiaries (3.267).

16 Somewhat paradoxically, the media has started to call this reporting cycle as quarter-to-quarter capitalism.

${ }^{17}$ Co-operatives may refer to their customer-owners by this category, whereas the other LT firm categories (government owned and family firms) may partly include ownership by other private Finnish owners including firm management. 
Politicians are seen to put highest short-term pressure on co-operatives (3.000). Also for jointly and government owned companies, the pressures from politicians are higher than for other firms, perhaps because there can be politicians in the boards (or supervisory boards). Government seems to be causing highest short-term pressure on government-owned companies (2.600), as well as on co-operatives and mutual insurance companies (2.000). One additional factor behind both politician and government induced pressure may be that such firms can have a significant market power in their sectors, thus being to a higher degree controlled by authorities.

Expectedly, family owners are the biggest source of short-term pressure on family-owned companies (3.238). Finnish institutional owners put surprisingly high short-term pressure on venture capitalist owned companies (3.375) and co-operatives and mutual insurance companies (3.333). In the first case, this could be caused by the fact that in Finland many institutional investors have invested in private equity funds.

Other Finnish and foreign owners put short-term pressure on jointly owned companies (3.600 and 4.333, respectively). However, samples are small in both categories. Workers and their unions are generally not experience to cause short-term pressure on companies. This result is as expected maximizing financial result in the short-run is against their interest.

\subsection{Actions taken to alleviate the short-term pressure}

Next the companies were asked, how they have modified their company's actions in response to the short-term pressure. Respondents were given a list of actions and they could respond 1 (not at all) through to 5 (to great extent) as well as 0 (not a relevant question). Respondents were also given a chance to explain how a certain action has been carried out. Results are reported in Table 4.

Panel A shows the results for the full sample. The number of companies providing an answer to each action varied between 144 and 147. When we calculate an average of the degree of action taken for each company, and relate it to the level of short-term pressure 
felt (as reported in Table 2), we obtain is significantly positive coefficient (a t-value of 3.12 in a simple OLS regression), suggesting that firms experiencing pressure are more prone to take actual actions. The short-term pressure had affected most strongly decisions concerning the required rate of return (or payback period) for the investments (average score is 3.022). Management compensation design (2.676) and financial reporting (2.667) obtain the second and third highest average scores when it comes to being influenced by short-term pressure.

Panels B and C of Table 4 show the results for LT and ST ownership categories. Comparing the results, we can see that the scores are as expected (i.e. in line with our hypothesis 3), generally on a higher level for ST firms. LT firms obtain higher scores only for dividend policy, long-term investments, and corporate governance, and in these cases with a marginal difference. The highest differences between the scores for ST and LT firms are obtained for compensation design, financial reporting, and payback period, each higher for ST firms. The fraction of "not relevant" answers is also always much lower for ST firms (ranging between 0 and 16.49 per cent, with an average of 6.27 across the action categories), as compared to LT firms (ranging between 10.42 to 25 per cent, with an average of 15.72). Using a $\chi^{2}$-test for group independent "not relevant" frequencies, we can reject the null hypothesis (at the $1 \%$ level) for compensation design, capital structure, corporate governance and the required rate of return, i.e. the question of short-term pressure affecting these variables is significantly less often "not relevant" among the ST firms.

We also analyze the responses in more detail with respect to the owner type. Panels D-K report the result for each stakeholder broken down to every ownership category. None of the actions appears to be overwhelmingly commonly applied in any category. However, government-owned companies feel much stronger than all the other firms that they have been forced to accommodate their dividend policy (average 3.375, as compared to averages between 2.000 and 2.714 for the others), long-term investments (3.000, as compared to values between 1.833 and 2.448), and corporate governance (3.333, as compared to values from 2.088 to 2.800). Government owned firms also produce the highest average score for the required rate of return (3.500). Private equity investors, in turn, deviate to some extent more from the others in terms of a high score of 3.200 for compensation design (as compared to values between 2.100 and 2.912 for the others) and financial reporting (3.400 
as compared to 1.700 to 3.000 ). They also have the highest average scores for capital structure (2.667), and personnel hiring / firing decisions (2.867).

Next, we rank, for each action, the average scores in the 7 ownership categories (as reported in panels $\mathrm{D}$ to $\mathrm{L}$ in table 4 ) from the highest to the lowest (a rank of 1 indicates that an ownership category has produced the highest average score for this action, whereas 7 indicates a lowest average score). These ranks as well as their averages are reported in Panel $\mathrm{M}$ of Table 4. We see that, not surprising, the lowest average rank $(1.88$, indicating that these firms are leading when it comes to accommodate short-term pressure) has been obtained for firms controlled by private equity investors. More surprising is the placement of government owned firms (an average rank of 2.00). Subsidiaries and listed firms rank on average as third or fourth (with average ranks of 3.33 and 4.00). Last in terms of ranking (the lowest pressure felt) are co-operatives (6.44), joint companies (5.22), and family firms (5.11). In general, these results are in line with our hypothesis concerning private equity, but go against our expectations for government owned firms.

\subsection{Horizon of the management compensation scheme}

The next two questions deal with the companies' executive management compensation scheme. First, the respondents were asked to indicate over what time horizon are the executives evaluated as far as their compensation goes. In practice, the respondents were asked to indicate whether the compensation is based mainly on performance measured over one, two, three years, or longer periods. If the respondent marked two answers, both were included. In these cases the response are often accompanied with an explanation indicating that the compensation is based on, e.g., one and three year performance.

Table 5 reports the results. The results in Panel A show that in vast majority of the responses (114 out of 146) the horizon of management's performance evaluation is mainly based on results calculated over one year. In only slightly more than sixteen per cent of the companies, evaluation of performance over three years or more is used. These results are somewhat worrying, indicating that management compensation favors above all actions, which lead to immediate result improvements. 
Panel A of Table 5 reports also the results for LT and ST sub-samples. The results show that the differences are small, the two largest differences being found for compensation systems of 2 and over 3 years, where ST firms dominate for the first alternative and LT firms for the second. However, the frequencies of firms in the combined groups of 1-2 years, versus 3 years or more, are roughly identical for ST and LT firms. Panel B shows the results categorized according to the ownership type. The results do not offer any major surprises. Publicly listed and family-owned companies report that they use slightly more often performance calculated over a couple of years. The better possibility to use options and share based payments in these firms (as compared to e.g. co-operatives) can be one reason for the result.

\subsection{Performance criteria for the management compensation scheme}

The respondents were also asked to indicate the most important measures used to evaluate management's performance. A list of five different measures was given with an option to provide a sixth one. Available alternatives included 1) relative profitability (e.g., ROI, ROCE), 2) profit level (e.g., EBITDA, EPS), 3) stock price or company market value, 4) growth, and 5) operational cash flow. Besides indicating whether a particular measure was used, the respondents were also asked to rank the measures used (one being most important, two being next most important etc.). If the respondent marked his or her choices with an ' $\mathrm{x}$ ' instead of indicating their rank, all marked items where given the same priority (one). Furthermore, if the respondent gave an additional criterion and it was clearly related to one of the provided criteria, manual correction was made. ${ }^{18}$

Since market-based measures should be more forward-looking as compared to historical profit figures, we expect that LT firms might use tem more frequently, i.e. use measures like the stock price or firm value. Also growth as compared to immediate profit may be

18 Typical cases included EVA (changed to answer number 2), options (changed to answer number 3), and sales growth (changed to answer number 4). EVA could have been assigned also to category 1 since it is based on the company's profit. However, it utilizes information of a rate-of-return requirement i.e. is also a measure of relative profitability, which supports the choice made here. There were altogether four "EVA"-answers, two among listed firms, one for a firm owned by private equity investors, and one for a $100 \%$ owned subsidiary. 
more acceptable as an (intermediate) target in firms with a long-term (ultimately market value maximizing) strategy.

Results are reported in Table 6. Panel A shows that an "absolute" profit variable (unrelated to capital invested) such as EBITDA or EPS is the most commonly used measure (123 companies report that it is used in their company) followed by relative profitability (105 companies) and growth (91 companies). For the majority of the firms, profit was also ranked as the most important one (obtaining an average rank of 1.336 among the 123 firms using it as one of the measures, with 72 per cent raking it as the highest), followed by relative profitability (an average rank of 1.924, with 41 per cent out of firms using it ranking it as the most important). However, five firms use "other" measures, and when such measures are used, these other measures actually even clearer obtain the rank of one (giving these "other" measures an average rank of 1.200). ${ }^{19}$ Such other measures mentioned include customer benefits, customer satisfaction, as well as Balanced Scorecard.

Results in Panel B report the frequency of inclusion of the different performance measures in executive compensation schemes of firms with different ownership structures. There are no major surprises. A valuation-based measure (stock price / market value) occurs often in listed firms (with 53 per cent of listed firms using it as one of the measures). Operational cash flow is most common among family firms and private equity firms, perhaps because these are most financially constrained - family firms because of the problems of loosing family control with outside owners, and private equity firms because of a high leverage. Co-operatives in turn seem to be least interested in using cash flow as a criterion. Growth is also less seldom used in co-operatives, whereas it is most often included as a criterion in joint companies and firms with significant private equity ownership.

In Panel $\mathrm{C}$, we report which performance measure is ranked as the most important one by each firm type. In terms of the relative weight put on the different criteria, and when looking only at measures used more often than 4 times per group, all firms independent of

19 This case shows that one should be cautious in interpreting the average rank, as the number of responses for each measure differs, and the companies were not asked to rank all of the measures. 
ownership type on average rank profit as the highest. ${ }^{20}$ Most firms also rank relative profit as number two, with the exception of private equity firms, who rank both growth and cash flow higher, and relative profitability and market valuation lower. This goes partly against our expectations, since we had categorized private equity firms as ST firms. The rankings of cash flow high, and relative profitability low, are in line with our expectation, whereas the rankings for growth (high) and market valuation (low) are not.

\subsection{Active company ownership structure management}

Another major goal of our survey was to find out if companies try to affect their ownership base. There can be several reasons behind active ownership management. As surveyed in section two of this paper, empirical research suggests that certain owners are more patient than others, i.e. willing to hold on to their investment longer. If this is the case, it may be in the company's interest to try to attract patient investors, if it leads to lower costs (e.g., due to stability of ownership) or if it maximizes company's value due to properly balanced short- and long-term investments. However, there could be alternative motives for the active ownership management that are not in the company's best interest. Namely, the management may find stability in the ownership to work in their favor as it may remove part of the principal-agent pressure.

To study the extent of ongoing ownership management, and its potential determinants, we asked the respondents if they the company had actively tried to influence its ownership structure. Respondents were given three choices: yes, to some degree, or no. Furthermore, if they had used some methods, they were asked to indicate what kind of methods they had used. Again, they were given a list of alternatives with an opportunity to add freely their own method(s). The respondents could choose multiple alternatives from the list. The results are reported in Table 7.

Somewhat surprisingly, the results show that 58 companies representing 39.46 per cent of respondents (147 for this question) have been involved in management of their ownership

20 It is motivated to look at measures used relatively more often, since a high average rank for an infrequently used measure can e.g. be produced by only one firm who uses it, and ranking it as the measure number one. 
structure at least to some degree. As expected, active ownership management seems to be clearly more common for the companies in the ST category as almost half of them gave a non-negative answer to the question $(47.96 \%$ vs. $20.84 \%){ }^{21}$

The most common used method has been the dividend policy (used in 55.17 per cent of the companies using active ownership management) followed by investor meetings (48.28 per cent), and reporting practices (37.93 per cent). The least used methods (except for the additional answers under the generic headline "other") are marketing and customer benefits $^{22}$ (5.17 per cent), various certificates, and stock issues (both at 15.52 per cent). Other methods provided by the respondents included e.g. generation shift (in a family firm), exit from the private equity investor (no exit method mentioned), and potential trade sale.

We also report the methods used in both LT and ST categories. Dividend policy seems to be clearly the main method of active ownership management for the LT companies, whereas investor meetings, public information releases, as well as the dividend policy are the most common methods for ST companies.

\subsection{Share repurchases}

We also asked the respondents whether the company had done share repurchases or not. Respondents were given three choices: often, occasionally, and no. Furthermore, they were asked to indicate what kind of reasons they had for the repurchases, in case they had done some. Again they were given a list of alternatives with an opportunity to add freely their own method(s). Multiple choices were again allowed. The results are reported in Table 8.

The results show that only 40 companies (27.40 per cent) out of 146 companies who responded to this question have done share repurchases at least occasionally. Share repurchases have been more common for the companies in the ST category as $33.34 \%$ of the ST companies gave a non-negative answer as opposed to 16.33 per cent of the LT

21 Some of the long-term firms can already e.g. have such an ownership structure (family firms and government owned) / firm type (co-operatives), that rapid changes in it are unlikely, and the firms therefore have lower incentives to use active ownership management.

22 These could include, e.g., issuing stocks or options to customers with purchases in excess of certain limit. Alternatively, company could offer rebates or cash-back bonuses to its owners. 
companies. This most likely relates to the fact that listed firms are included in the ST category.

Had the repurchases been done, the most common reasons for them were development of the company's ownership structure (16 companies, 40 per cent), development of the company's capital structure (13 companies, 32.50 per cent), followed by company stock undervaluation (10 companies, 25 per cent). Surprisingly only two companies quote tax reasons as a motivation for repurchases. In the academic literature share repurchases has been mostly explained and encouraged by tax advantages.

None of the companies indicates that it has been the wish of domestic investors and only three companies quote foreign owners' wishes as the reason for the repurchases. Similarly, the aim to improve company's accounting ratios was quoted only in one case. Other quoted the reasons for the share repurchases included acquisitions, a generation shift, and to acquire shares that can be used in executive compensation plans.

The results also show that LT firms use share repurchases only to develop their ownership structure (seven responses, one company did not indicate the justification for share repurchases), whereas ST companies had more diverse reasons for the repurchases.

\subsection{Long-term R\&D investments}

The last three questions in the questionnaire deal with the companies' investment. They are used to test for potential links between a short-term focus on one hand, and lower willingness to invest in very long-term projects, a higher required rate of return, or a shorter payback period on the other. Furthermore, the questions are similar to the ones used in earlier studies, and can thus be used to compare results. The first question is "how much of their R\&D expenditure is aimed at projects on which you expect no profit during the next five years?" This questions is similar to Segelod (2000) and Poterba and Summers (1995). The results are reported in Table 9.

We received 109 non-empty responses to this question. The results indicate that Finnish companies direct only on average 9.065 per cent of their investments into this kind of 
projects. This is surprisingly low number as Poterba and Summers (1995) report using their sample of 139 U.S. companies an average of 22.6 per cent. Segelod (2000) report even higher average for Swedish companies, namely 25.4 per cent. Somewhat surprisingly, ST firms seem to invest somewhat more (9.7 per cent) than LT firms (7.8 per cent). However, the standard deviations are large, and the difference is not statistically significant in a t-test assuming unequal variances (a t-value of 0.66 ).

Panel B shows that publicly listed companies seem to have the highest R\&D expenditures in long-term investments $(12.796 \%)$ followed by co-operatives $(10.600 \%)$. Somewhat surprisingly, family-owned companies do not seem to invest heavily in long-term project without any hope of immediate profits. Their average is among the lowest (6.545\%).

Next we asked how much more the company would invest in long term investments if the stock market would value your company correctly. The results are reported in Table 10 . We received 68 responses to this question. The results show that on average companies would invest 9.963 per cent more. This is surprisingly high percentage if compared to Segelod (2000), who report an average of 5.8 per cent for the Swedish companies. Poterba and Summers (1995) on the other hand report an average of 20.7 per cent. ${ }^{23}$

There is a large difference between ST and LT firms, ST firms (which include listed firms) reporting a much higher percentage of 12.074 as compared to 5.238 for LT firms. This is in line with our expectations, but difference is not statistically significant (a t-value of 1.05). We also have to keep in mind that this question is above all directed towards publicly listed companies (or firms potentially considering a listing). Co-operatives show the highest percentage, but the response rate is only two. The categories with five or more answers are firms owned by private equity investors (who report a percentage of 17.5), publicly listed firms (16.8), subsidiaries (7.2), joint companies (4.0) and family firms (0.67), and these

\footnotetext{
23 All the firms reporting a non-zero percentage for this question, i.e. indicating that they would invest more if they would be properly valuated, also reported a rather high number for questions concerning the shortterm pressures felt (questions I.1. and I.2., summarized in Tables 2 and 3). For question I.1, the answers were a pressure level of 3 or higher (with four exemptions at 2), while for question I.2., the answers were at least a pressure level of 4 (with two exemptions at 2) for at least one ownership category. This indicates that the questions I.1 and I.2 were properly understood by these recipients, i.e. that they report on "negative" short-term pressure, a pressure that they feel is in conflict with the long-term optimal goals of the company.
} 
answers rank according to prior expectations, the ST firms (the first four groups) having higher percentages i.e. suffering more from the market's perceived short-term focus, and family firms suffering the least. ${ }^{24}$

Finally, the respondents were asked to indicate the payback period (in years) for the company's investments as well as their nominal hurdle rate for investments. We received answers for the first part of the question from 110 companies and for the second part from 99 companies. The descriptive statistics of the answers are reported in Table 11. Note that if the respondents gave a range, the average of the range was used in the analysis. If the range of was open-ended (such as $>11$ per cent), it was excluded from the analysis.

Panel A shows that the average payback period for the full sample is 5.009 years (median 3.500 years). This is somewhat higher than in Sweden as Segelod (2000) reports payback years to vary between 3.0 years for replacement investments and 4.9 years for the investments in new areas.

On the other hand, the average required rate of return, 15.485 per cent (median $15.000 \%$ ), is close to Segelod (2000) results for Sweden. Liljeblom and Vaihekoski (2004) reported an average of 15.19 percent for the Finnish publicly listed companies in 2004, as did Keloharju and Puttonen (1995) ten years earlier. Poterba and Summers (1995) also report similar results (average rate of $15.5 \%$ ). This indicates that collectively the average required rate of return (hurdle rate) does not vary especially much, either over time or across countries.

It is somewhat surprising to see that the required rate of return for investments seem to stay at the 15 per cent level year in, year out despite the fact that interest rate level has significantly changed e.g. from the mid-1990s. Moreover, its level seems surprisingly high,

\footnotetext{
This result is supported by an analysis of the ST and LT groups when excluding two "outliers" of 100 per cent or more, one among the co-operatives, and one among the listed firms. Excluding these two observations produces new ST and LT averages of 7.99 and 0.50 per cent (with standard deviations of 11.83 and 2.24), and a t-value of 4.13 , significant at the $1 \%$ level.
} 
as it can easily be shown that with the current interest rate levels and expectations for the market risk premium ${ }^{25}$, the WACC for most companies is likely to be below ten per cent.

Panel $\mathrm{B}$ and $\mathrm{C}$ shows the payback period and required rate of return for LT \& ST subsamples. The results show that LT firms are, as expected (our hypothesis 9), using longer payback periods (5.3 as compared to 4.8 for ST firms) as well as a lower discount rate (12.8 per cent as compared to 17.07). The difference between the payback periods (ST minus LT) is not statistically significant (a t-value of -0.59 ), whereas the difference between the rates of return is (a t-value of 2.22, significant at the $5 \%$ level).

Panel D of table 11 shows the results for seven ownership categories. The average payback periods and discount rates are, as expected, negatively correlated (a correlation of -0.26 for the 80 firms answering both questions, a correlation of -0.62 between the seven group averages). The clearly highest average required rates of return (25.1 per cent) are asked by private equity investors, followed by listed firms (17.0 per cent) and subsidiaries (14.3 per cent), all classified as ST firms. ${ }^{26}$ In this analysis, government owned firms seem to be among the most patient, with the lowest rate of return requirement of 9.833 per cent, and the second longest payback period of 7.714 years. Also joint companies reflect modest discount periods and the longest payback periods, most likely reflecting that such firms have been set up to serve some industry group on a more long term, and not purely profit maximizing basis (such as common equipment producers, distribution channels, or service providers for several separate firms in a related industry).

25 For Finnish data, see e.g. the results from the most recent survey by PriceWaterhouseCoopers (2005) on the market risk premium. Based on the results from a questionnaire to central Finnish market actors, they report average values between 5.5\% and 4.3\% for 1 and 30 year expected risk premiums in Finland in 2005.

26 We asked for the required rate of return for the investment, not the ROE, so these high rates in private equity firms should not as such reflect the higher than average leverage in such firms. 


\section{CONCLUSIONS}

Increased media exposure to layoffs and corporate quarterly financial reporting have created arguable a common perception - especially favored by the media itself - that the companies have been forced to improve their financial performance from quarter to quarter. Academically the relevant question is whether companies themselves feel that are exposed short-term pressure to perform even if it means that they have to compromise company's long-term future. This paper studies this issue using results from a survey conducted among the 500 largest companies in Finland. This study updates and to some extent extends earlier studies by Poterba and Summers (1995) and Segelod (2000).

The results show that companies in general feel moderate short-term pressure, with a reasonable dispersion around the mean of 2.8 (on a scale from 1 to 5). There are also clear relationships between the company's ownership structure and the short-term pressure that the company faces, and accommodates for in its actions. The aspect of ownership was included in the analysis by sorting the 148 identifiable respondents into seven ownership groups (subsidiaries, co-operatives, government firms, family firms, joint companies, private equity owned firms, and listed firms). Furthermore, we analyzed results for two larger subgroups, expectedly more short-term oriented firms (ST firms) and more longer term oriented firms (LT firms).

The results indicate that our classification was at least partly successful. ST firms were found to experience significantly more short-term pressure. The source of this pressure varied across firm types, but in general ST firms experienced significantly more pressure from external market / diversified investor sources such as financial analysts and foreign owners, whereas LT firms were significantly more subject to pressure from the government and family owners.

There were also differences between how the firms feel that they have to accommodate for short-term pressure when determining firm policies. For several corporate actions (compensation design, capital structure, corporate governance, and the required rate of return), ST firms significantly less often considered the question of the need to 
accommodate for short-term pressure in corporate actions to be irrelevant. Across all actions, the highest average rank in terms of the degree to which short-term pressure is accommodated for, was not surprisingly obtained by firms with significant private equity ownership. Government owned firms, more surprisingly, ranked as number two.

We also asked specific questions concerning management compensation plans, dividend policy / share repurchases, as well as the amount of long-term investments and investment selection criteria, in order to test for whether a higher pressure for short-termism in fact is reflected in these variables. Whereas there were small differences between the management compensation plans for ST and LT firms (most being surprisingly short-term), or the actual variables in these plans, there were differences between how much more the ST and LT firms would invest if the market would value such investments more properly. ST firms seemed in this respect more constrained by the experienced short-term focus of the market. Finally, the ST and LT firms differed in terms of the investment criteria used. The average pay-back period was shorter, and the discount rate longer, the latter more significantly so, in ST firms as compared to LT firms.

This study contributes by studying a scientifically relatively novel, but topical question of whether firms actually feel pressure to compromise long-term goals in favor of short-term ones because of outside pressures. We also investigate the sources and consequences of such pressure. We find support for the existence of differences between ownership categories in terms of the short-term pressure they put on the firm. We also find that these pressures seem to cause company specific differences in e.g. the amount of long-term investments, and the investment criteria used. Thus these seems to be some substance, at least in terms of experienced pressure at the firm level, in the popular journalist view of at least some firms suffering under the "quarter economy". 


\section{REFERENCES}

Bethel, J. E.- Liebeskind, J. P. - Opler, T., 1998, Block Share Purchases and Corporate Performance. Journal of Finance 53, 605-634.

Bogle, J., 2003, The Mutual Fund Industry in 2003: Back to the Future, Exhibit IV in Statement before the U.S. House of Representatives Committee on Financial Services, 12/03/2003 (available at http://financialservices.house.gov/media/pdf/031203jb.pdf).

Bushee, B., 1998, The Influence of Institutional Investors on Myopic R\&D Investment Behavior. The Accounting Review 73, 305-333.

Bushee, B. - Noe, C. F., 2000, Corporate Disclosure Practices, Institutional Investors, and Stock Return Volatility. Journal of Accounting Research 38, Supplement: Studies on Accounting Information and the Economics of the Firm, 171-202.

Bøhren, Ø. - Priestley, R. - Ødegaard B. A., 2004, Ownership duration, monitoring quality, and myopic firms. Norwegian School of Managemen, working paper.

Chen, X. - Harford, J. - Li, K., 2005, Monitoring: Which institutions matter? MIT Sloan School of Management, working paper.

Clay, D., 2000, The effects of institutional investment on CEO compensation. University of Southern California, working paper.

Dahlquist, M. - Robertson, G., 2001, Direct foreign ownership, institutional investors, and firm characteristics. Journal of Financial Economics 59, 413-440.

Dikolli, S. S. - Kulp, S. L. - Sedatole, K. L., 2003, CEO horizon, investor horizon, and the contracting use of forward-looking performance measures, University of Texas at Austin, working paper.

Dobrzynski, J., 1993, Relationship investing: a new shareholder is emerging - patient and involved. Business Week, March 15, 68-75.

Gaspar, J.-M. - Massa, M. - Matos, P. - Patgiri, R. - Rehman, Z., 2005a, Can Buybacks be a product of Shorter Shareholder Horizons? CEPR Discussion Paper 4813.

Gaspar, J.-M. - Massa, M. - Matos, P., 2005b, Shareholder Investment Horizons and the Market for Corporate Control. Journal of Financial Economics 76, 135-165. 
Gompers, P. - Metrick, A., 2001, Institutional Investors and Equity Prices. Quarterly Journal of Economics 116, 229-259.

Graham, J. R. - Harvey, C. R., 2001, The theory and practice of corporate finance. Journal of Financial Economics 60, 187-243.

Hartzell, J. - Starks, L., 2003, Institutional Investors and Executive Compensation. Journal of Finance 58, 2351-2373.

Keloharju, M. - Puttonen, V., 1995, Suomalaisyritysten investointilaskelmat ja suunnitteluhorisontti. Finnish Journal of Business and Economics 44, No 3, 316-332.

Liljeblom, E. - Löflund, A., 2005, Determinants of International Portfolio Investment Flows to a Small Market: Empirical Evidence. Journal of Multinational Financial Management 15, 211-233.

Liljeblom, E. - Vaihekoski, M., 2004, Investment Evaluation Methods and Required Rate of Return in Finnish Publicly listed Companies. Finnish Journal of Business and Economics 54, 9-24.

Maury, B. - Pajuste A., 2005, Multiple Large Shareholders and Firm Value. Journal of Banking \& Finance 29, 1813-1834.

Monks, R. - Minow, N., 1995, Corporate governance. Cambridge, MA; Blackwell.

Poterba, J. M. - Summers, L. W., 1995, A CEO Survey of U.S. Companies' Time Horizon and Hurdle Rates. Sloan Management Review 37, 43-53.

PriceWaterhouseCoopers, 2005, Markkinariskipreemio suomen osakemarkkinoilla, http://www.pwc.com/fi/fin/issues/publ/markkinariskipreemio_05.pdf

Puttonen, V., 2004, Does Ownership Matter? Finnish Business Policy Forum Reports, in Finnish.

Segelod, E., 2000, A Comparison of Managers' Perceptions of Short-Termism in Sweden and the U.S. International Journal of Production Economics 63, 243-254.

Sias, R., 1996, Volatility and the Institutional Investor. Financial Analysts Journal 521, 1321. 


\section{Figure 1. Distribution of ownership categories}

Figure shows the breakdown of the companies' ownership background in the sample of 149 companies. The ownership category could not be determined for one company.

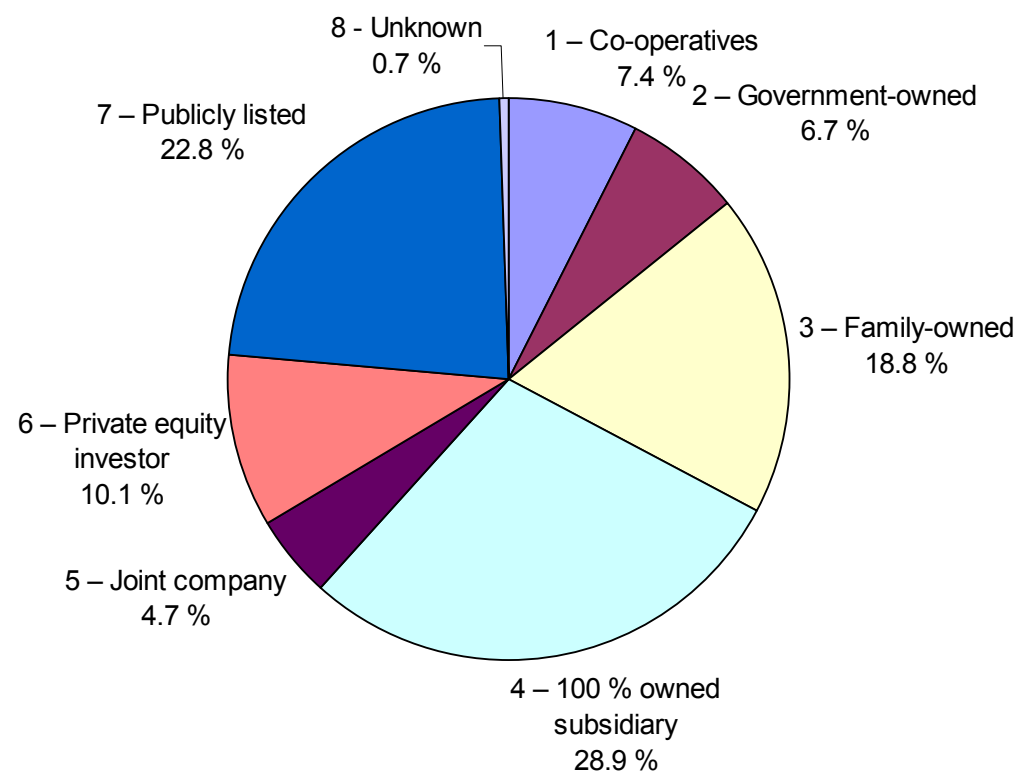




\section{Table 1. Descriptive statistics}

Descriptive statistics are reported for the 500 largest companies in Finland (TOP500) and for the companies that responded to the survey (respondents). Panel A reports the number of responses categorized on the basis of TOP500-ranking. Panel B reports key financial ratios for the 500 largest companies and respondents. For individual statistics, the number of companies could vary according if the information is unknown or unavailable.

\begin{tabular}{lrrrr}
\hline \hline & \multicolumn{2}{c}{ TOP 500 } & Respondents \\
\hline PANEL A: Number of responses & & & & \\
\hline N & 500 & $100.0 \%$ & 149 & $29.8 \%$ \\
TOP500 ranking: 001-100 & 100 & $20.0 \%$ & 44 & $30.1 \%$ \\
\multicolumn{1}{c}{ 101-200 } & 100 & $20.0 \%$ & 18 & $12.1 \%$ \\
\multicolumn{1}{c}{$301-400$} & 100 & $20.0 \%$ & 26 & $17.8 \%$ \\
\multicolumn{1}{c}{$401-500$} & 100 & $20.0 \%$ & 29 & $19.9 \%$ \\
\hline PANEL B: Financial statistics & 100 & $20.0 \%$ & 30 & $20.5 \%$ \\
\hline Mean turnover (mill. $€$ ) & 500 & 591.2 & 147 & 741.2 \\
Mean net profit (mill. $€$ ) & 500 & 28.4 & 121 & 13.6 \\
Mean investments & 500 & 32.0 & 132 & 40.2 \\
Mean number of employees & 500 & 1920.0 & 146 & 2787.0 \\
\hline \hline
\end{tabular}


Table 2. Pressure on compromising long-term goals in favor of short-term goals

Respondents were asked to reply how much pressure they feel towards compromising company's long-term goals in favor of short-term goals. Answers were given on a 1 (very weak) to 5 (very strong) scale with an option to answer 0 (not relevant). Panel A reports the results for the full sample as well as long and short-term investors, and Panel B separately for seven different ownership categories. $N$ indicates the number of respondents, with the response rate in parenthesis. Not relevant (\%) column reports the number of responses with an answer indicating that the question is not relevant for the company. Reported means, medians and standard deviations have been calculated from 1-5 responses.

\begin{tabular}{lrrrrr}
\hline \hline & & & & & \multicolumn{2}{c}{$\begin{array}{c}\text { Not } \\
\text { relevant } \\
\text { (\%) }\end{array}$} \\
\hline Panel A: Full sample & & Mean & Median & Std. dev. & \\
\hline All & 148 & 2.838 & 3.000 & 1.176 & $12.16 \%$ \\
Long-term owners & 48 & 2.289 & 2.000 & 1.250 & $20.83 \%$ \\
Short-term owners & 99 & 3.077 & 3.000 & 1.088 & $8.08 \%$ \\
\hline Panel B: Ownership categories & & & & & \\
\hline 1- Co-operative & 11 & 1.875 & 2.000 & 0.835 & $27.27 \%$ \\
2- Government-owned & 10 & 2.600 & 3.000 & 1.265 & $0.00 \%$ \\
3- Family-owned & 27 & 2.300 & 2.000 & 1.380 & $25.93 \%$ \\
\hline 4- 100 \% owned subsidiary & 43 & 3.051 & 3.000 & 1.075 & $9.30 \%$ \\
5- Joint company & 7 & 2.500 & 2.500 & 1.789 & $14.29 \%$ \\
6- Private equity investor & 15 & 3.067 & 3.000 & 1.163 & $0.00 \%$ \\
7- Publicly listed & 34 & 3.226 & 4.000 & 1.087 & $8.82 \%$ \\
\hline \hline
\end{tabular}




\section{Table 3. Sources of short-term pressure}

Respondents were asked to reply how much short-term pressure certain stakeholders cause for the company. Answers were given on a 1 (very weak) to 5 (very strong) scale with an option to answer 0 (not relevant). Panel A reports the results for the full sample, and Panels B-C for long- and short-term owners. Panels D-L report the results separately for seven different ownership categories. $N$ indicates the number of respondents, with the response rate in parenthesis. Not relevant (\%) column reports the number of responses with an answer indicating that the question is not relevant for the company. Reported means, medians and standard deviations have been calculated from 1-5 responses.

\begin{tabular}{llcccc}
\hline \hline & Mean & Median & Std. dev. & $\begin{array}{c}\text { Not } \\
\text { relevant } \\
\text { (\%) }\end{array}$ \\
\hline Panel A: Full sample & & & & & \\
\hline Media & 125 & 2.505 & 2.000 & 1.152 & $14.40 \%$ \\
Analysts & 124 & 3.129 & 4.000 & 1.312 & $25.00 \%$ \\
Politicians & 123 & 1.838 & 1.000 & 1.111 & $39.84 \%$ \\
Government (as owner) & 122 & 1.600 & 1.000 & 0.955 & $67.21 \%$ \\
Family owners & 125 & 2.694 & 3.000 & 1.370 & $42.40 \%$ \\
Finnish institutional owners & 124 & 2.523 & 2.000 & 1.226 & $47.58 \%$ \\
Other Finnish owners & 124 & 2.878 & 3.000 & 1.182 & $40.32 \%$ \\
Foreign owners & 125 & 3.463 & 4.000 & 1.167 & $34.40 \%$ \\
Workers and their unions & 124 & 1.798 & 2.000 & 0.923 & $24.19 \%$ \\
\hline Panel B: Long-term owners & & & & & \\
\hline Media & 38 & 2.556 & 2.000 & 1.188 & $28.95 \%$ \\
Analysts & 38 & 1.950 & 1.000 & 1.234 & $47.37 \%$ \\
Politicians & 37 & 1.944 & 2.000 & 1.056 & $51.35 \%$ \\
Government (as owner) & 38 & 2.000 & 1.500 & 1.333 & $73.68 \%$ \\
Family owners & 38 & 3.120 & 4.000 & 1.364 & $34.21 \%$ \\
Finnish institutional owners & 37 & 2.500 & 2.500 & 1.434 & $72.97 \%$ \\
Other Finnish owners & 37 & 3.071 & 3.000 & 1.207 & $62.16 \%$ \\
Foreign owners & 37 & 2.375 & 2.500 & 1.302 & $78.38 \%$ \\
Workers and their unions & 37 & 1.952 & 2.000 & 1.071 & $43.24 \%$ \\
\hline
\end{tabular}


Table 3 Continued

\begin{tabular}{|c|c|c|c|c|c|}
\hline & $\mathbf{N}$ & Mean & Median & Std. dev. & $\begin{array}{l}\text { Not } \\
\text { relevant } \\
(\%)\end{array}$ \\
\hline \multicolumn{6}{|l|}{ Panel C: Short-term owners } \\
\hline Media & 86 & 2.494 & 2.000 & 1.153 & $8.14 \%$ \\
\hline Analysts & 85 & 3.458 & 4.000 & 1.150 & $15.29 \%$ \\
\hline Politicians & 85 & 1.818 & 1.000 & 1.140 & $35.29 \%$ \\
\hline Government (as owner) & 83 & 1.483 & 1.000 & 0.785 & $65.06 \%$ \\
\hline Family owners & 86 & 2.435 & 2.000 & 1.328 & $46.51 \%$ \\
\hline Finnish institutional owners & 86 & 2.556 & 2.500 & 1.192 & $37.21 \%$ \\
\hline Other Finnish owners & 86 & 2.847 & 3.000 & 1.186 & $31.40 \%$ \\
\hline Foreign owners & 87 & 3.616 & 4.000 & 1.062 & $16.09 \%$ \\
\hline Workers and their unions & 86 & 1.736 & 2.000 & 0.872 & $16.28 \%$ \\
\hline \multicolumn{6}{|l|}{ Panel D: Media } \\
\hline 1 - Co-operative & 6 & 3.000 & 3.000 & 1.000 & $50.00 \%$ \\
\hline 2 - Government-owned & 10 & 2.778 & 3.000 & 1.093 & $10.00 \%$ \\
\hline 3 - Family-owned & 22 & 2.333 & 2.000 & 1.291 & $31.82 \%$ \\
\hline $4-100 \%$ owned subsidiary & 36 & 2.515 & 2.000 & 1.253 & $8.33 \%$ \\
\hline 5 - Joint company & 6 & 3.000 & 3.000 & 1.581 & $16.67 \%$ \\
\hline 6 - Private equity investor & 13 & 1.900 & 2.000 & 0.876 & $23.08 \%$ \\
\hline 7 - Publicly listed & 31 & 2.581 & 2.000 & 1.025 & $0.00 \%$ \\
\hline \multicolumn{6}{|l|}{ Panel E: Analysts } \\
\hline 1 - Co-operative & 6 & 2.500 & 2.500 & 0.707 & $66.67 \%$ \\
\hline 2 - Government-owned & 10 & 2.143 & 1.000 & 1.464 & $30.00 \%$ \\
\hline 3 - Family-owned & 22 & 1.727 & 1.000 & 1.191 & $50.00 \%$ \\
\hline $4-100 \%$ owned subsidiary & 36 & 3.267 & 4.000 & 1.413 & $16.67 \%$ \\
\hline 5 - Joint company & 6 & 2.667 & 2.000 & 2.082 & $50.00 \%$ \\
\hline 6 - Private equity investor & 13 & 3.222 & 4.000 & 1.093 & $30.77 \%$ \\
\hline 7 - Publicly listed & 30 & 3.800 & 4.000 & 0.610 & $0.00 \%$ \\
\hline
\end{tabular}


Table 3 Continued

\begin{tabular}{|c|c|c|c|c|c|}
\hline & $\mathbf{N}$ & Mean & Median & Std. dev. & $\begin{array}{c}\text { Not } \\
\text { relevant } \\
(\%)\end{array}$ \\
\hline \multicolumn{6}{|l|}{ Panel F: Politicians } \\
\hline 1 - Co-operative & 6 & 3.000 & 3.000 & 1.000 & $50.00 \%$ \\
\hline 2 - Government-owned & 9 & 2.286 & 2.000 & 1.113 & $22.22 \%$ \\
\hline 3 - Family-owned & 22 & 1.250 & 1.000 & 0.463 & $63.64 \%$ \\
\hline $4-100 \%$ owned subsidiary & 35 & 2.045 & 2.000 & 1.253 & $37.14 \%$ \\
\hline 5 - Joint company & 6 & 2.600 & 3.000 & 1.517 & $16.67 \%$ \\
\hline 6 - Private equity investor & 13 & 1.857 & 2.000 & 1.069 & $46.15 \%$ \\
\hline 7 - Publicly listed & 31 & 1.381 & 1.000 & 0.805 & $32.26 \%$ \\
\hline \multicolumn{6}{|c|}{ Panel G: Government as an owner } \\
\hline 1 - Co-operative & 6 & 2.000 & 2.000 & $\mathrm{n} / \mathrm{a}$ & $83.33 \%$ \\
\hline 2 - Government-owned & 10 & 2.600 & 3.000 & 1.673 & $50.00 \%$ \\
\hline 3 - Family-owned & 22 & 1.250 & 1.000 & 0.500 & $81.82 \%$ \\
\hline $4-100 \%$ owned subsidiary & 35 & 1.600 & 1.000 & 1.075 & $71.43 \%$ \\
\hline 5 - Joint company & 6 & 1.667 & 2.000 & 0.577 & $50.00 \%$ \\
\hline 6 - Private equity investor & 13 & 1.333 & 1.000 & 0.577 & $76.92 \%$ \\
\hline 7 - Publicly listed & 29 & 1.385 & 1.000 & 0.650 & $55.17 \%$ \\
\hline \multicolumn{6}{|l|}{ Panel H: Family owners } \\
\hline 1 -Co-operative & 6 & 2.000 & 2.000 & $\mathrm{n} / \mathrm{a}$ & $83.33 \%$ \\
\hline 2 - Government-owned & 9 & 2.667 & 3.000 & 1.528 & $66.67 \%$ \\
\hline 3 - Family-owned & 23 & 3.238 & 4.000 & 1.375 & $8.70 \%$ \\
\hline $4-100 \%$ owned subsidiary & 36 & 2.250 & 2.000 & 1.390 & $55.56 \%$ \\
\hline 5 - Joint company & 6 & 1.000 & 1.000 & $\mathrm{n} / \mathrm{a}$ & $83.33 \%$ \\
\hline 6 - Private equity investor & 13 & 2.286 & 2.000 & 1.254 & $46.15 \%$ \\
\hline 7 - Publicly listed & 31 & 2.682 & 3.000 & 1.323 & $29.03 \%$ \\
\hline \multicolumn{6}{|c|}{ Panel I: Finnish institutional owners } \\
\hline 1 -Co-operative & 6 & 3.333 & 4.000 & 1.155 & $50.00 \%$ \\
\hline 2 - Government-owned & 10 & 2.667 & 3.000 & 1.528 & $70.00 \%$ \\
\hline 3 - Family-owned & 21 & 1.750 & 1.000 & 1.500 & $80.95 \%$ \\
\hline $4-100 \%$ owned subsidiary & 36 & 1.643 & 1.000 & 0.929 & $61.11 \%$ \\
\hline 5 - Joint company & 6 & 2.500 & 2.500 & 0.707 & $66.67 \%$ \\
\hline 6 - Private equity investor & 13 & 3.375 & 4.000 & 1.598 & $38.46 \%$ \\
\hline 7 - Publicly listed & 31 & 2.767 & 3.000 & 0.971 & $3.23 \%$ \\
\hline
\end{tabular}


Table 3 Continued

\begin{tabular}{|c|c|c|c|c|c|}
\hline & $\mathbf{N}$ & Mean & Median & Std. dev. & $\begin{array}{l}\text { Not } \\
\text { relevant } \\
(\%)\end{array}$ \\
\hline \multicolumn{6}{|c|}{ Panel J: Other Finnish owners } \\
\hline 1 - Co-operative & 6 & 3.000 & 3.000 & 1.225 & $16.67 \%$ \\
\hline 2 - Government-owned & 9 & 3.000 & 3.000 & 1.000 & $66.67 \%$ \\
\hline 3 - Family-owned & 22 & 3.167 & 3.500 & 1.472 & $72.73 \%$ \\
\hline $4-100 \%$ owned subsidiary & 35 & 1.933 & 1.000 & 1.280 & $57.14 \%$ \\
\hline 5 - Joint company & 6 & 3.600 & 4.000 & 0.548 & $16.67 \%$ \\
\hline 6 - Private equity investor & 14 & 3.333 & 3.000 & 1.225 & $35.71 \%$ \\
\hline 7 - Publicly listed & 31 & 3.033 & 3.000 & 0.964 & $3.23 \%$ \\
\hline \multicolumn{6}{|l|}{ Panel K: Foreign owners } \\
\hline $1-$ Co-operative & 6 & 3.000 & 3.000 & $\mathrm{n} / \mathrm{a}$ & $83.33 \%$ \\
\hline 2 - Government-owned & 10 & 2.500 & 2.500 & 2.121 & $80.00 \%$ \\
\hline 3 - Family-owned & 21 & 2.200 & 2.000 & 1.304 & $76.19 \%$ \\
\hline $4-100 \%$ owned subsidiary & 37 & 3.848 & 4.000 & 1.093 & $10.81 \%$ \\
\hline 5 - Joint company & 6 & 4.333 & 4.000 & 0.577 & $50.00 \%$ \\
\hline 6 - Private equity investor & 14 & 3.500 & 4.000 & 1.069 & $42.86 \%$ \\
\hline 7 - Publicly listed & 30 & 3.310 & 4.000 & 1.004 & $3.33 \%$ \\
\hline \multicolumn{6}{|c|}{ Panel L: Workers and their unions } \\
\hline $1-$ Co-operative & 6 & 2.000 & 1.500 & 1.414 & $33.33 \%$ \\
\hline 2 - Government-owned & 9 & 2.000 & 2.000 & 0.894 & $33.33 \%$ \\
\hline 3 - Family-owned & 22 & 1.909 & 1.000 & 1.136 & $50.00 \%$ \\
\hline $4-100 \%$ owned subsidiary & 36 & 1.933 & 2.000 & 1.015 & $16.67 \%$ \\
\hline 5 - Joint company & 6 & 1.833 & 1.500 & 0.983 & $0.00 \%$ \\
\hline 6 - Private equity investor & 13 & 1.600 & 2.000 & 0.516 & $23.08 \%$ \\
\hline 7 - Publicly listed & 31 & 1.538 & 1.000 & 0.761 & $16.13 \%$ \\
\hline
\end{tabular}




\section{Table 4. Actions to accommodate short-term pressure}

Respondents were asked if they had accommodated their actions in respond to the short-term pressure. Respondents were given a list of actions and asked to indicate whether the short-term pressure had had an effect while making decisions on that particular action. Answers were given on a 1 (very little) to 5 (very much) scale with an option to answer 0 (not relevant). Panel A reports the results for the full sample, and Panels B-C for long- and short-term owners. Panels D-L report the results separately for seven different ownership categories. $N$ indicates the number of respondents, with the response rate in parenthesis. Not relevant $(\%)$ column reports the number of responses with an answer indicating that the question is not relevant for the company. Reported mean, median and standard deviation are calculated from valid responses between one and five. Finally, panel M ranks, for each of the actions, the average scores obtained in each of the seven ownership categories (with a value of 1 for the ownership category producing the highest average score, and 7 for the one producing the lowest score, for the action in question).

\begin{tabular}{|c|c|c|c|c|c|}
\hline & $\mathbf{N}$ & Mean & Median & Std. dev. & $\begin{array}{l}\text { Not } \\
\text { relevant } \\
(\%)\end{array}$ \\
\hline \multicolumn{6}{|l|}{ Panel A: Full sample } \\
\hline Compensation design & 146 & 2.676 & 3.000 & 1.205 & $4.79 \%$ \\
\hline Dividend policy & 146 & 2.436 & 2.000 & 1.228 & $19.86 \%$ \\
\hline Capital structure & 144 & 2.271 & 2.000 & 1.004 & $10.42 \%$ \\
\hline Long-term investments & 146 & 2.250 & 2.000 & 1.088 & $17.81 \%$ \\
\hline Hiring / layoff decisions & 146 & 2.522 & 3.000 & 1.112 & $5.48 \%$ \\
\hline R\&D expenditure & 146 & 2.115 & 2.000 & 1.006 & $10.96 \%$ \\
\hline Financial reporting & 147 & 2.667 & 3.000 & 1.264 & $6.12 \%$ \\
\hline Corporate Governance & 147 & 2.429 & 2.000 & 1.205 & $4.76 \%$ \\
\hline Required rate / Payback period & 144 & 3.022 & 3.000 & 1.086 & $4.86 \%$ \\
\hline \multicolumn{6}{|l|}{ Panel B: Long-term owners } \\
\hline Compensation design & 48 & 2.310 & 2.000 & 1.093 & $12.50 \%$ \\
\hline Dividend policy & 48 & 2.444 & 2.000 & 1.403 & $25.00 \%$ \\
\hline Capital structure & 47 & 2.081 & 2.000 & 1.064 & $21.28 \%$ \\
\hline Long-term investments & 47 & 2.324 & 2.000 & 1.248 & $21.28 \%$ \\
\hline Hiring / layoff decisions & 47 & 2.333 & 2.000 & 1.203 & $10.64 \%$ \\
\hline$R \& D$ expenditure & 47 & 1.846 & 2.000 & 0.933 & $17.02 \%$ \\
\hline Financial reporting & 48 & 2.372 & 2.000 & 1.254 & $10.42 \%$ \\
\hline Corporate Governance & 48 & 2.429 & 2.000 & 1.252 & $12.50 \%$ \\
\hline Required rate / Payback period & 46 & 2.732 & 3.000 & 1.162 & $10.87 \%$ \\
\hline
\end{tabular}


Table 4 Continued

\begin{tabular}{|c|c|c|c|c|c|}
\hline & $\mathbf{N}$ & Mean & Median & Std. dev. & $\begin{array}{l}\text { Not } \\
\text { relevant } \\
(\%)\end{array}$ \\
\hline \multicolumn{6}{|l|}{ Panel C: Short-term owners } \\
\hline Compensation design & 97 & 2.835 & 3.000 & 1.272 & $0.00 \%$ \\
\hline Dividend policy & 97 & 2.432 & 2.000 & 1.234 & $16.49 \%$ \\
\hline Capital structure & 96 & 2.330 & 2.000 & 1.096 & $5.21 \%$ \\
\hline Long-term investments & 98 & 2.207 & 2.000 & 1.130 & $16.33 \%$ \\
\hline Hiring / layoff decisions & 98 & 2.600 & 3.000 & 1.143 & $3.06 \%$ \\
\hline$R \& D$ expenditure & 98 & 2.233 & 2.000 & 1.092 & $8.16 \%$ \\
\hline Financial reporting & 98 & 2.787 & 3.000 & 1.286 & $4.08 \%$ \\
\hline Corporate Governance & 98 & 2.412 & 2.000 & 1.231 & $1.02 \%$ \\
\hline Required rate / Payback period & 97 & 3.137 & 3.000 & 1.107 & $2.06 \%$ \\
\hline \multicolumn{6}{|c|}{ Panel D: Management compensation design } \\
\hline $1-$ Co-operative & 11 & 2.100 & 2.000 & 0.876 & $9.09 \%$ \\
\hline 2 - Government-owned & 9 & 2.875 & 3.000 & 1.126 & $11.11 \%$ \\
\hline 3 - Family-owned & 28 & 2.208 & 2.000 & 1.141 & $14.29 \%$ \\
\hline $4-100 \%$ owned subsidiary & 41 & 2.732 & 3.000 & 1.323 & $0.00 \%$ \\
\hline 5 - Joint company & 7 & 2.286 & 2.000 & 1.113 & $0.00 \%$ \\
\hline 6 - Private equity investor & 15 & 3.200 & 4.000 & 1.207 & $0.00 \%$ \\
\hline 7 - Publicly listed & 34 & 2.912 & 3.000 & 1.264 & $0.00 \%$ \\
\hline \multicolumn{6}{|l|}{ Panel E: Dividend policy } \\
\hline 1 - Co-operative & 11 & 2.000 & 1.500 & 1.265 & $45.45 \%$ \\
\hline 2 - Government-owned & 9 & 3.375 & 4.000 & 1.188 & $11.11 \%$ \\
\hline 3 - Family-owned & 28 & 2.227 & 2.000 & 1.412 & $21.43 \%$ \\
\hline $4-100 \%$ owned subsidiary & 41 & 2.233 & 2.000 & 1.431 & $26.83 \%$ \\
\hline 5 - Joint company & 7 & 2.714 & 3.000 & 1.380 & $0.00 \%$ \\
\hline 6 - Private equity investor & 15 & 2.636 & 3.000 & 1.362 & $26.67 \%$ \\
\hline 7 - Publicly listed & 34 & 2.485 & 3.000 & 0.972 & $2.94 \%$ \\
\hline
\end{tabular}


Table 4 Continued

\begin{tabular}{|c|c|c|c|c|c|}
\hline & $\mathbf{N}$ & Mean & Median & Std. dev. & $\begin{array}{l}\text { Not } \\
\text { relevant } \\
(\%)\end{array}$ \\
\hline \multicolumn{6}{|c|}{ Panel F: Company's capital structure } \\
\hline 1 - Co-operative & 11 & 1.667 & 1.000 & 0.866 & $18.18 \%$ \\
\hline 2 - Government-owned & 8 & 2.500 & 2.500 & 0.535 & $0.00 \%$ \\
\hline 3 - Family-owned & 28 & 2.100 & 2.000 & 1.252 & $28.57 \%$ \\
\hline $4-100 \%$ owned subsidiary & 41 & 2.351 & 2.000 & 1.086 & $9.76 \%$ \\
\hline 5 - Joint company & 7 & 1.500 & 1.000 & 0.837 & $14.29 \%$ \\
\hline 6 - Private equity investor & 15 & 2.667 & 2.000 & 1.397 & $0.00 \%$ \\
\hline 7 - Publicly listed & 33 & 2.303 & 2.000 & 0.951 & $0.00 \%$ \\
\hline \multicolumn{6}{|c|}{ Panel G: Long-term investments } \\
\hline 1 - Co-operative & 11 & 1.900 & 1.500 & 1.287 & $9.09 \%$ \\
\hline 2 - Government-owned & 8 & 3.000 & 3.000 & 1.000 & $12.50 \%$ \\
\hline 3 - Family-owned & 28 & 2.300 & 2.000 & 1.261 & $28.57 \%$ \\
\hline $4-100 \%$ owned subsidiary & 42 & 2.030 & 2.000 & 1.045 & $21.43 \%$ \\
\hline 5 - Joint company & 7 & 1.833 & 1.500 & 0.983 & $14.29 \%$ \\
\hline 6 - Private equity investor & 15 & 2.286 & 2.000 & 1.437 & $6.67 \%$ \\
\hline 7 - Publicly listed & 34 & 2.448 & 2.000 & 1.088 & $14.71 \%$ \\
\hline \multicolumn{6}{|c|}{ Panel H: Personnel hiring / layoff decisions } \\
\hline 1 - Co-operative & 10 & 1.625 & 1.000 & 1.061 & $20.00 \%$ \\
\hline 2 - Government-owned & 9 & 2.556 & 2.000 & 0.726 & $0.00 \%$ \\
\hline 3 - Family-owned & 28 & 2.480 & 3.000 & 1.327 & $10.71 \%$ \\
\hline $4-100 \%$ owned subsidiary & 42 & 2.675 & 3.000 & 1.185 & $4.76 \%$ \\
\hline 5 - Joint company & 7 & 2.286 & 2.000 & 1.113 & $0.00 \%$ \\
\hline 6 - Private equity investor & 15 & 2.867 & 3.000 & 1.125 & $0.00 \%$ \\
\hline 7 - Publicly listed & 34 & 2.455 & 3.000 & 1.121 & $2.94 \%$ \\
\hline \multicolumn{6}{|l|}{ Panel I: R\&D expenditure } \\
\hline $1-$ Co-operative & 11 & 1.800 & 1.000 & 1.135 & $9.09 \%$ \\
\hline 2 - Government-owned & 8 & 2.000 & 2.000 & 0.535 & $0.00 \%$ \\
\hline 3 - Family-owned & 28 & 1.810 & 1.000 & 0.981 & $25.00 \%$ \\
\hline $4-100 \%$ owned subsidiary & 42 & 2.378 & 2.000 & 1.277 & $11.90 \%$ \\
\hline 5 - Joint company & 7 & 1.333 & 1.000 & 0.516 & $14.29 \%$ \\
\hline 6 - Private equity investor & 15 & 2.357 & 2.000 & 0.929 & $6.67 \%$ \\
\hline 7 - Publicly listed & 34 & 2.182 & 2.000 & 0.950 & $2.94 \%$ \\
\hline
\end{tabular}


Table 4 Continued

\begin{tabular}{|c|c|c|c|c|c|}
\hline & $\mathbf{N}$ & Mean & Median & Std. dev. & $\begin{array}{l}\text { Not } \\
\text { relevant } \\
\text { (\%) }\end{array}$ \\
\hline \multicolumn{6}{|l|}{ Panel J: Financial reporting } \\
\hline 1 - Co-operative & 11 & 1.700 & 1.500 & 0.823 & $9.09 \%$ \\
\hline 2 - Government-owned & 9 & 3.000 & 3.000 & 0.866 & $0.00 \%$ \\
\hline 3 - Family-owned & 28 & 2.417 & 2.000 & 1.412 & $14.29 \%$ \\
\hline $4-100 \%$ owned subsidiary & 42 & 2.872 & 3.000 & 1.418 & $7.14 \%$ \\
\hline 5 - Joint company & 7 & 2.333 & 1.500 & 1.751 & $14.29 \%$ \\
\hline 6 - Private equity investor & 15 & 3.400 & 4.000 & 1.183 & $0.00 \%$ \\
\hline 7 - Publicly listed & 34 & 2.500 & 2.500 & 0.992 & $0.00 \%$ \\
\hline \multicolumn{6}{|c|}{ Panel K: Corporate Governance } \\
\hline 1 - Co-operative & 11 & 2.300 & 2.000 & 1.337 & $9.09 \%$ \\
\hline 2 - Government-owned & 9 & 3.333 & 3.000 & 0.707 & $0.00 \%$ \\
\hline 3 - Family-owned & 28 & 2.130 & 2.000 & 1.254 & $17.86 \%$ \\
\hline $4-100 \%$ owned subsidiary & 42 & 2.512 & 2.000 & 1.306 & $2.38 \%$ \\
\hline 5 - Joint company & 7 & 2.571 & 3.000 & 1.618 & $0.00 \%$ \\
\hline 6 - Private equity investor & 15 & 2.800 & 2.000 & 1.320 & $0.00 \%$ \\
\hline 7 - Publicly listed & 34 & 2.088 & 2.000 & 0.965 & $0.00 \%$ \\
\hline \multicolumn{6}{|c|}{ Panel L: Required rate of return / payback period } \\
\hline 1 - Co-operative & 11 & 2.200 & 2.000 & 1.229 & $9.09 \%$ \\
\hline 2 - Government-owned & 8 & 3.500 & 3.500 & 0.926 & $0.00 \%$ \\
\hline 3 - Family-owned & 27 & 2.696 & 3.000 & 1.105 & $14.81 \%$ \\
\hline $4-100 \%$ owned subsidiary & 41 & 3.300 & 4.000 & 1.159 & $2.44 \%$ \\
\hline 5 - Joint company & 7 & 3.000 & 4.000 & 1.633 & $0.00 \%$ \\
\hline 6 - Private equity investor & 15 & 3.400 & 3.000 & 0.910 & $0.00 \%$ \\
\hline 7 - Publicly listed & 34 & 2.848 & 3.000 & 0.972 & $2.94 \%$ \\
\hline
\end{tabular}


Table 4 Continued

\begin{tabular}{|c|c|c|c|c|c|c|c|c|c|c|}
\hline \multicolumn{11}{|c|}{ Panel M: Ranks of average scores for each action $(1=$ highest score, $7=$ lowest $)$} \\
\hline $\begin{array}{l}\left.\text { Corporate action }{ }^{*}\right) \\
\text { (as reported in Panels D to L) }\end{array}$ & $\mathrm{D}$ & $\mathrm{E}$ & $\mathrm{F}$ & G & $\mathrm{H}$ & $\mathrm{I}$ & $\mathrm{J}$ & $\mathrm{K}$ & $\mathrm{L}$ & $\begin{array}{l}\text { Averag } \\
\text { e rank }\end{array}$ \\
\hline $1-$ Co-operative & 7 & 7 & 6 & 6 & 7 & 6 & 7 & 5 & 7 & 6.44 \\
\hline 2 - Government-owned & 3 & 1 & 2 & 1 & 3 & 4 & 2 & 1 & 1 & 2.00 \\
\hline 3 - Family-owned & 6 & 6 & 5 & 3 & 4 & 5 & 5 & 6 & 6 & 5.11 \\
\hline $4-100 \%$ owned subsidiary & 4 & 5 & 3 & 5 & 2 & 1 & 3 & 4 & 3 & 3.33 \\
\hline 5 - Joint company & 5 & 2 & 7 & 7 & 6 & 7 & 6 & 3 & 4 & 5.22 \\
\hline 6 - Private equity investor & 1 & 3 & 1 & 4 & 1 & 2 & 1 & 2 & 2 & 1.88 \\
\hline 7 - Publicly listed & 2 & 4 & 4 & 2 & 5 & 3 & 4 & 7 & 5 & 4.00 \\
\hline
\end{tabular}

*) The actions are: $\mathrm{D}$ = management compensation design, $\mathrm{E}$ = dividend policy, $\mathrm{F}$ = company's capital structure, $\mathrm{G}=$ long-term investments, $\mathrm{H}=$ personnel hiring / layoff decisions, $\mathrm{I}=\mathrm{R} \& \mathrm{D}$ expenditure, $\mathrm{J}$ = financial reporting, $\mathrm{K}=$ corporate governance, and $\mathrm{L}=$ required rate of return / payback period. 
Table 5. Horizon of the management compensation plan

Respondents were asked what is the time horizon on which the company's compensation plan for the top management is mostly based on. Available alternatives included 1-3 years, or more than three years. Panel A reports the number of replies for each alternative together with their relative share of the total number of responses for the full sample as well as long and short-term investors. Panel B reports the number of replies for each alternative separately for seven different ownership categories. $N$ indicates the number of responses.

\begin{tabular}{|c|c|c|c|c|c|}
\hline & $\mathbf{N}$ & 1 year & 2 years & 3 years & $>3$ years \\
\hline \multicolumn{6}{|l|}{ Panel A: All respondents } \\
\hline All & 146 & 114 & 8 & 18 & 6 \\
\hline (\% of responses) & & $78.08 \%$ & $5.48 \%$ & $12.33 \%$ & $4.11 \%$ \\
\hline Long-term owners & 42 & 34 & 1 & 4 & 3 \\
\hline (\% of responses) & & $80.95 \%$ & $2.38 \%$ & $9.52 \%$ & $7.14 \%$ \\
\hline Short-term owners & 104 & 80 & 7 & 14 & 3 \\
\hline (\% of responses) & & $76.92 \%$ & $6.73 \%$ & $13.46 \%$ & $2.88 \%$ \\
\hline \multicolumn{6}{|c|}{ Panel B: Categorized with respect to ownership type } \\
\hline 1 - Co-operative & 11 & 11 & 0 & 0 & 0 \\
\hline 2 - Government-owned & 8 & 6 & 0 & 2 & 0 \\
\hline 3 - Family-owned & 23 & 17 & 1 & 2 & 3 \\
\hline $4-100 \%$ owned subsidiary & 45 & 40 & 0 & 4 & 1 \\
\hline 5 - Joint company & 6 & 5 & 0 & 1 & 0 \\
\hline 6 - Private equity investor & 16 & 14 & 1 & 1 & 0 \\
\hline 7 - Publicly listed & 37 & 21 & 6 & 8 & 2 \\
\hline
\end{tabular}




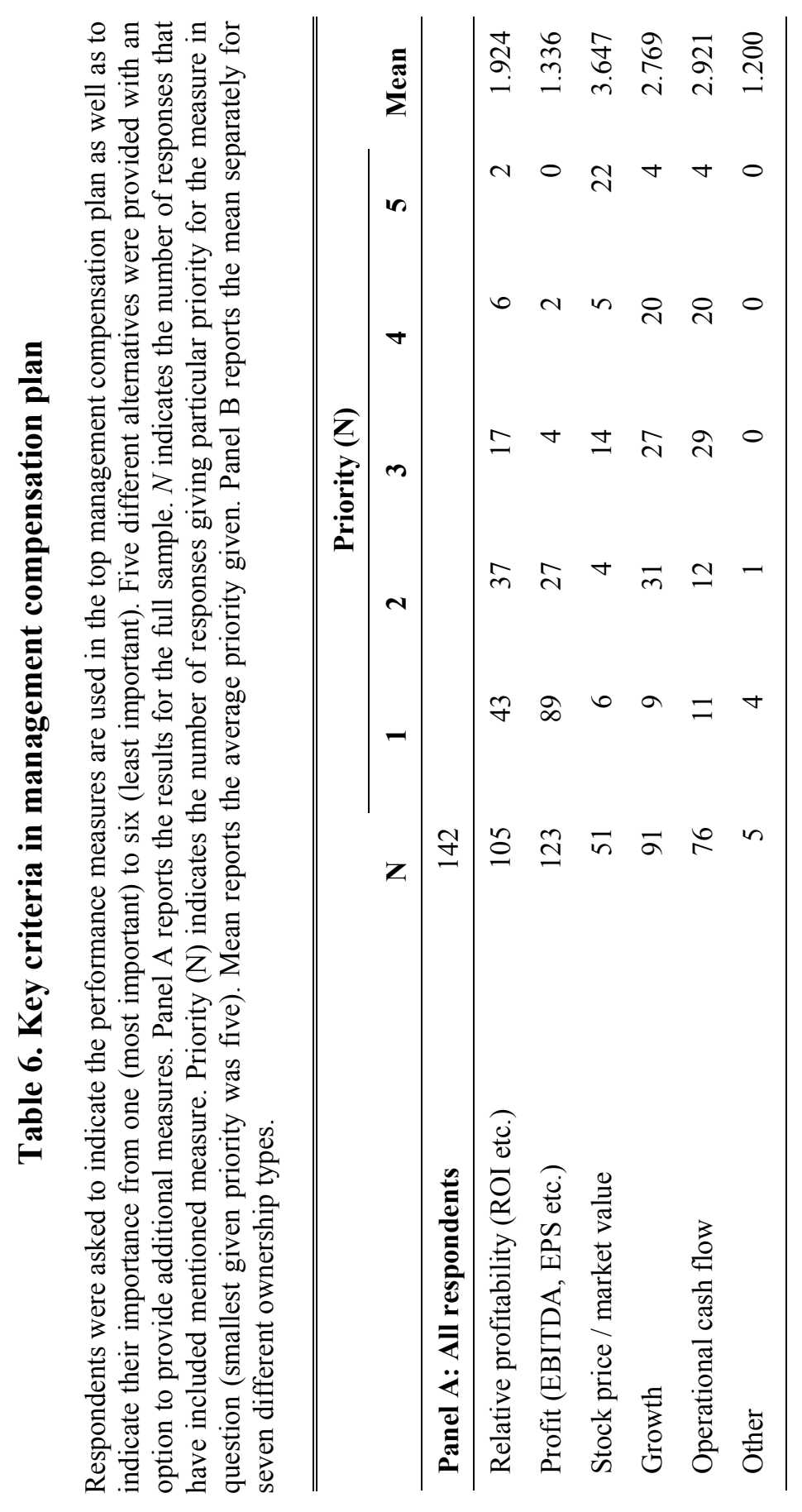




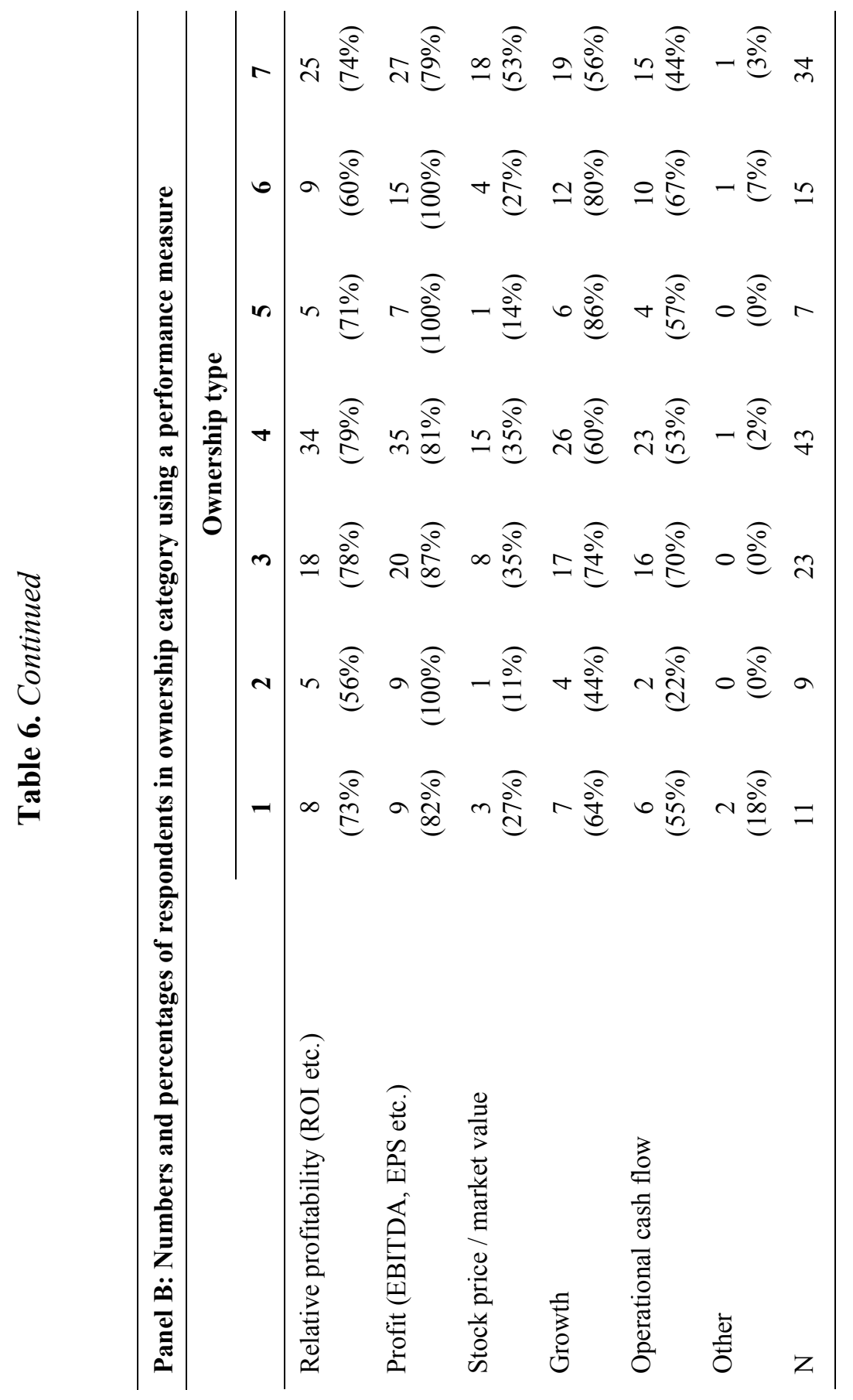




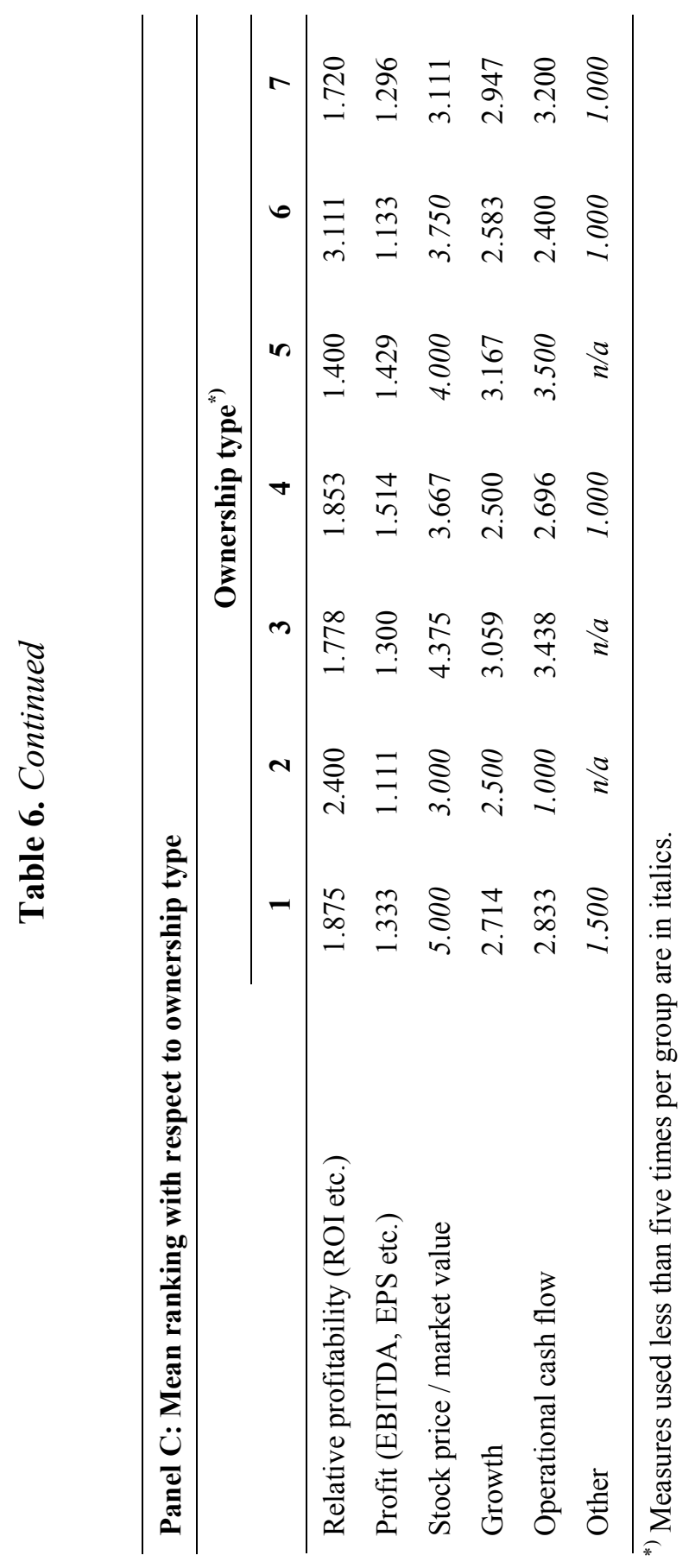




\section{Table 7. Active ownership structure management}

Respondents were asked to indicate whether the company has actively been involved in developing the company's ownership structure. Available alternatives includes yes, to some degree, and no. If the answer was 'yes' or 'to some degree', the respondents were asked to indicate what kind of method(s) they had used. Nine different alternatives were provided with an option to provide additional methods. Panel A reports the results for the first question. Reported values indicate the number of responses together with their percentage share first for all respondents and then for LT and ST groups. Panel B reports frequency of each method being used among those who did not answer 'no'. Percentage values indicate the popularity of each method among companies actively managing their ownership structure.

\begin{tabular}{|c|c|c|c|c|}
\hline & $\mathbf{N}$ & Yes & $\begin{array}{c}\text { To some } \\
\text { degree }\end{array}$ & No \\
\hline \multicolumn{5}{|c|}{ Panel A: Has the company tried to influence ownership structure } \\
\hline All & 147 & $\begin{array}{r}18 \\
12.24 \%\end{array}$ & $\begin{array}{r}40 \\
27.21 \%\end{array}$ & $\begin{array}{r}89 \\
60.54 \%\end{array}$ \\
\hline LT & 48 & $\begin{array}{r}2 \\
4.17 \%\end{array}$ & $\begin{array}{r}8 \\
16.67 \%\end{array}$ & $\begin{array}{r}38 \\
79.17 \%\end{array}$ \\
\hline ST & 98 & $\begin{array}{r}16 \\
16.33 \%\end{array}$ & $\begin{array}{r}31 \\
31.63 \%\end{array}$ & $\begin{array}{r}51 \\
52.04 \%\end{array}$ \\
\hline Panel B: Method of management & $\mathbf{N}$ (all) & $\%$ (all) & $\mathbf{N}(\mathbf{L T})$ & $\mathbf{N}(\mathbf{S T})$ \\
\hline Dividend policy & 32 & $55.17 \%$ & 8 & 24 \\
\hline Various certificates & 9 & $15.52 \%$ & 0 & 9 \\
\hline Investor meetings & 28 & $48.28 \%$ & 2 & 26 \\
\hline Public information releases & 27 & $46.55 \%$ & 2 & 24 \\
\hline Stock issues & 9 & $15.52 \%$ & 1 & 8 \\
\hline Marketing / customer benefits & 3 & $5.17 \%$ & 1 & 2 \\
\hline Financial reporting & 23 & $39.66 \%$ & 3 & 19 \\
\hline IPO & 10 & $17.24 \%$ & 1 & 9 \\
\hline Development of Corporate Governance & 13 & $22.41 \%$ & 2 & 10 \\
\hline Other & 5 & $8.62 \%$ & 1 & 4 \\
\hline
\end{tabular}




\section{Table 8. Share repurchases}

Respondents were asked to indicate whether the company has repurchased its shares. Available alternatives included yes, occasionally, and no. If the answer was yes or occasionally, the respondents were asked to indicate what were the main justifications for the repurchases. Eight different alternatives were provided with an option to provide additional justifications. Panel A reports the results for the first question. Reported values indicate the number of responses together with their percentage share first for all respondents and then for LT and ST groups. Panel B reports frequency of a justification being marked as a reason for repurchases. Percentage value indicates the popularity of each justification among companies who have done share repurchases.

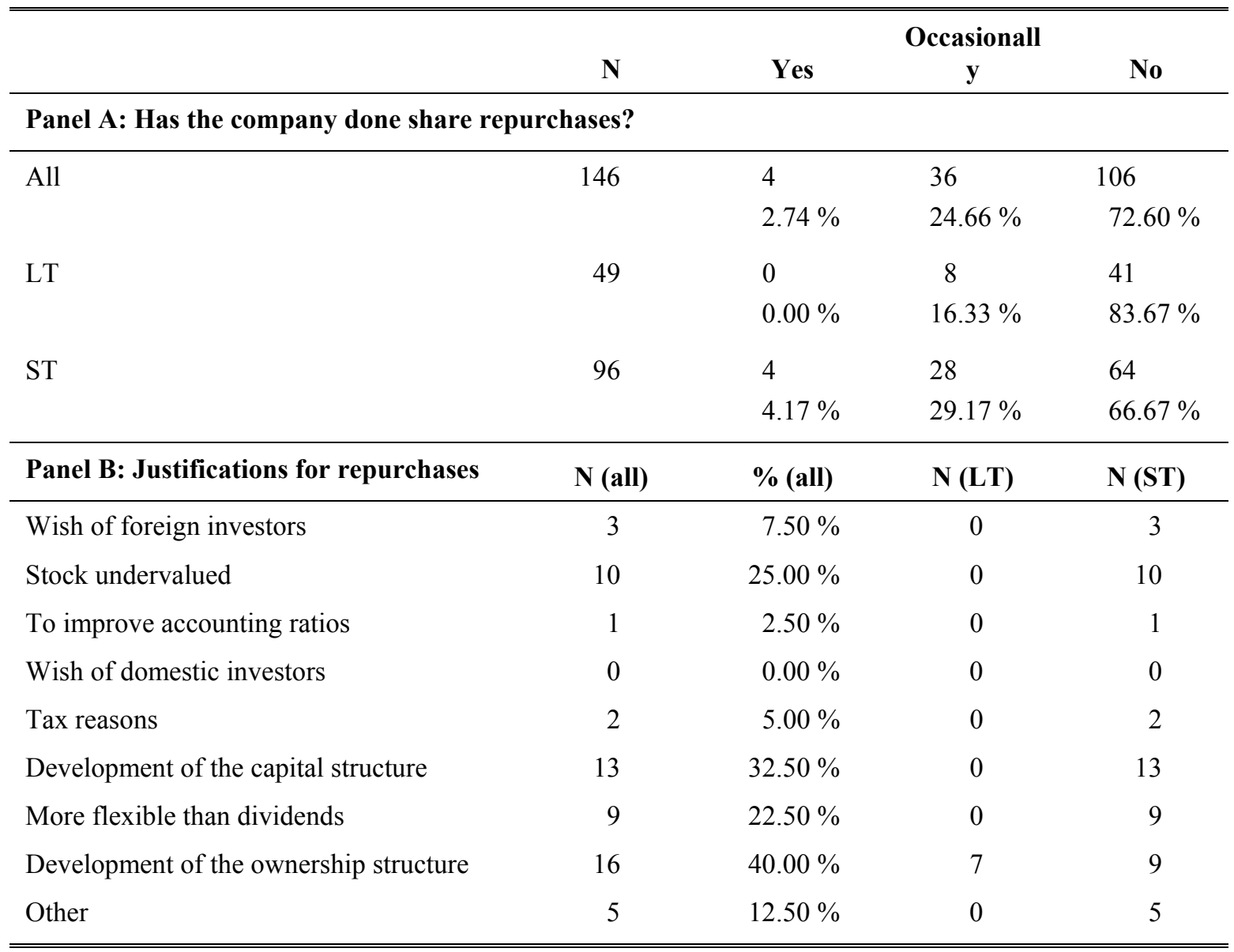




\section{Table 9. Long-term R\&D investments}

The respondents were asked to estimate the proportion of company's R\&D expenditure is aimed to projects that are not expected to provide profits in the next five years (\%). Panel A reports the results for the full sample as well as long and short-term investors, and Panel B separately for seven different ownership categories. $N$ indicates the number of responses. Reported mean, median and standard deviation are calculated from non-empty responses.

\begin{tabular}{lcccc}
\hline \hline & N & Average & Median & Std. dev. \\
\hline Panel A: All respondents & & & & \\
\hline All & 109 & 9.065 & 0.000 & 17.143 \\
Long-term owners & 33 & 7.788 & 0.000 & 11.255 \\
Short-term owners & 75 & 9.748 & 0.000 & 19.283 \\
\hline Panel B: Categorized with respect to ownership type & 10.600 & 0.000 & 15.225 \\
\hline 1 - Co-operative & 5 & 10.000 & 7.500 & 11.402 \\
2- Government-owned & 6 & 6.545 & 0.000 & 10.631 \\
$3-$ Family-owned & 22 & 9.850 & 0.000 & 21.277 \\
\hline $4-100 \%$ owned subsidiary & 30 & 2.857 & 0.000 & 4.880 \\
5 - Joint company & 7 & 6.373 & 0.100 & 8.963 \\
6 - Private equity investor & 11 & 12.796 & 3.000 & 22.129 \\
7 - Publicly listed & 27 & & & \\
\hline \hline
\end{tabular}




\section{Table 10. Stock market valuation and investments}

The respondents were asked to estimate how much more the company would invest if the stock market would value these long-term investments correctly. Panel A reports the results for the full sample as well as long and short-term investors, and Panel B separately for seven different ownership categories. $\mathrm{N}$ indicates the number of responses. Reported mean, median and standard deviation are calculated from non-empty responses.

\begin{tabular}{lcccc}
\hline \hline & N & Average & Median & Std. dev. \\
\hline Panel A: All respondents & \multicolumn{5}{c}{} & & \\
\hline All & 68 & 9.963 & 0.000 & 28.014 \\
Long-term owners & 21 & 5.238 & 0.000 & 21.822 \\
Short-term owners & 47 & 12.074 & 0.000 & 30.353 \\
\hline Panel B: Categorized with respect to ownership type & & \\
\hline 1 - Co-operative & 2 & 50.000 & 50.000 & 70.711 \\
2 - Government-owned & 4 & 0.000 & 0.000 & 0.000 \\
3 - Family-owned & 15 & 0.667 & 0.000 & 2.582 \\
\hline 4 - 100 \% owned subsidiary & 17 & 7.206 & 5.000 & 8.922 \\
5 - Joint company & 5 & 4.000 & 0.000 & 8.944 \\
6 - Private equity investor & 8 & 17.500 & 15.000 & 19.086 \\
7 - Publicly listed & 17 & 16.765 & 0.000 & 48.022 \\
\hline \hline
\end{tabular}




\section{Table 11. Payback period and required rate of return}

The respondents were asked to give the payback period (years) and nominal required rate of return for the investments (\%). Panel A reports the results for the full sample, Panels B and C for long- and short-term owners, and Panel D separately for seven different ownership categories. $N$ indicates the number of responses. Reported mean, median and standard deviation are calculated from given responses.

\begin{tabular}{|c|c|c|c|c|}
\hline & $\mathbf{N}$ & Average & Median & Std. dev. \\
\hline \multicolumn{5}{|l|}{ Panel A: All respondents } \\
\hline Payback period (years) & 110 & 5.009 & 3.500 & 4.737 \\
\hline Required rate of return (\%) & 99 & 15.485 & 15.000 & 10.787 \\
\hline \multicolumn{5}{|l|}{ Panel B: Long-term owners } \\
\hline Payback period (years) & 39 & 5.308 & 5.000 & 3.585 \\
\hline Required rate of return (\%) & 37 & 12.824 & 10.000 & 6.579 \\
\hline \multicolumn{5}{|l|}{ Panel C: Short-term owners } \\
\hline Payback period (years) & 70 & 4.800 & 3.000 & 5.305 \\
\hline Required rate of return (\%) & 62 & 17.073 & 15.000 & 12.432 \\
\hline \multicolumn{5}{|c|}{$\begin{array}{l}\text { Panel D: Categorized with respect to ownership type } \\
\text { (payback period first row, required rate of return in italics on the second row) }\end{array}$} \\
\hline 1 - Co-operative & $\begin{array}{l}8 \\
7\end{array}$ & $\begin{array}{r}6.500 \\
11.357\end{array}$ & $\begin{array}{r}5.500 \\
10.000\end{array}$ & $\begin{array}{l}3.196 \\
3.805\end{array}$ \\
\hline 2 - Government-owned & $\begin{array}{l}7 \\
6\end{array}$ & $\begin{array}{l}7.714 \\
9.833\end{array}$ & $\begin{array}{l}5.000 \\
9.500\end{array}$ & $\begin{array}{l}6.020 \\
1.835\end{array}$ \\
\hline 3 - Family-owned & $\begin{array}{l}24 \\
24\end{array}$ & $\begin{array}{r}4.208 \\
14.000\end{array}$ & $\begin{array}{r}3.250 \\
13.250\end{array}$ & $\begin{array}{l}2.269 \\
7.668\end{array}$ \\
\hline $4-100 \%$ owned subsidiary & $\begin{array}{l}32 \\
20\end{array}$ & $\begin{array}{r}3.656 \\
14.300\end{array}$ & $\begin{array}{r}3.000 \\
15.000\end{array}$ & $\begin{array}{l}3.171 \\
5.190\end{array}$ \\
\hline 5 - Joint company & $\begin{array}{l}6 \\
5\end{array}$ & $\begin{array}{l}12.333 \\
11.000\end{array}$ & $\begin{array}{r}7.500 \\
10.000\end{array}$ & $\begin{array}{r}14.010 \\
8.718\end{array}$ \\
\hline 6 - Private equity investor & $\begin{array}{l}11 \\
11\end{array}$ & $\begin{array}{r}3.318 \\
25.136\end{array}$ & $\begin{array}{r}3.000 \\
20.000\end{array}$ & $\begin{array}{r}1.250 \\
25.575\end{array}$ \\
\hline 7 - Publicly listed & $\begin{array}{l}21 \\
26\end{array}$ & $\begin{array}{r}5.167 \\
16.962\end{array}$ & $\begin{array}{r}5.000 \\
17.750\end{array}$ & $\begin{array}{l}3.344 \\
6.380\end{array}$ \\
\hline
\end{tabular}




\section{APPENDIX}

\section{The Questionnaire (original)}

\section{HANKEN \\ Svenska
handelshögskolar}

Kaikkia vastauksia käsitellään luottamuksellisesti.

I MIELIPIDE-KYSYMYKSET

TEKNILLINEN YLIOPISTO

TULOS TAI ULOS - omistajuus kvartaalitaloudessa -tutkimus

1. Oletteko kokeneet, että yrityksen ulkopuolelta tulevat odotukset lyhyen aikavälin jatkuvista tulosparannuksista luovat ristiriitaa pitkän tähtäimen tavoitteiden kanssa?

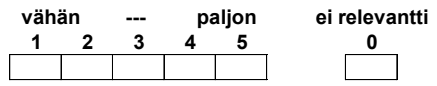

2. Jos kyllä, kuinka paljon seuraavat tahot aiheuttavat yrityksellenne suurinta lyhyen aikavälin menestymispainetta:

Media

Analyytikot

Poliittiset vaikuttaja

Valtio-omistaja

Perheomistajat

Kotim. institutionaaliset omistajat (eläkeyhtiöt tmv.)

Kotimaiset omistajat, muut

Ulkomaiset omistajat

Työntekijät / ammattiyhdistysliikkeet

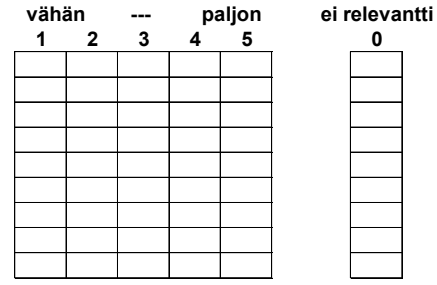

II KÄYTÄNNÖT

1. Onko yrityksenne sopeuttanut toimintaansa / ottanut lyhyen aikavälin menestymispaineet huomioon muotoillessaan/päättäessään yhtiön ...
a. johdon palkitsemisjärjestelmiä
b. osinkopolitiikkaa
c. pääomarakennetta
d. pitkäaikaisia sijoituksia
. työllistämispäätöksiä / irtisanomisia
f. T\&K-menojen suuruutta
g. taloudellista raportointipolitiikkaa
h. yrityksen hyvää hallintotapaa (CG)
i. investointien tuottovaatimusta / takaisinmaksuaikaa

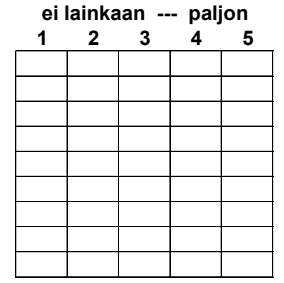

ei relevantti

2. Painottuuko yrityksenne ylimmän johdon palkitsemisjärjestelmissä eniten yhden, kahden, kolmen vai yli kolmen vuoden tulosmittarit?

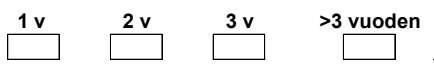

Lisäselvitys, jos tarpeen:

3. Aseta seuraavat tulosmittarit tärkeysjärjestykseen yrityksenne ylimmän johdon palkitsemisjärjetelmässä (1. tärkein jne., tyhjä = ei käytössä):

Kannattavuus (ROI, ROCE tms.)

Tulostaso (EBITDA, EPS, tms.)

Yrityksen pörssikurssi / markkina-arvo

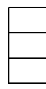

Kasvu

Operatiivinen kassavirta

Muu, mikä? Tärkeysjärjestys?

4. Pyritäänkö yrityksen päätöksenteossa aktiivisesti vaikuttamaan omistusrakenteen kehitykseen pitkällä aikavälillä?

Jos kyllä tai jossain määrin, käytetyt keinot:

$\begin{array}{lll}\text { Kyllä } & \text { Jossain määrin } \\ \text { Osinko- } & \text { Erilaiset toimin- } & \text { Sijoittaja- } \\ \text { politiikka } & \text { nan sertifioinnit } & \text { Muut keinot, mitkä? }\end{array}$


5. Onko yrityksenne tehnyt osakkeiden takaisinostoja?

Jos usein tai satunnaisesti, keskeiset perustelut takaisinostoille:

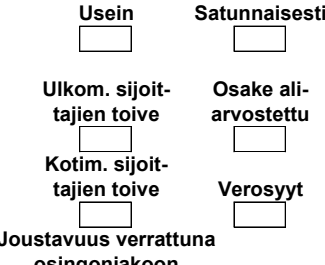

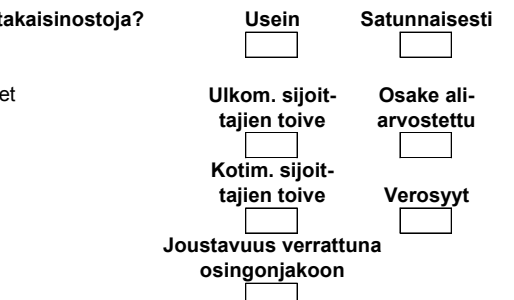

Ei lainkaan

Tunnuslukujen parantaminen

Pääomarakenteen tehostaminen Omistusrakentee kehittäminen

Muu syyt, mitkä?

6. Mikä osuus arviolta yrityksen T\&K-menoista on arviolta suunnattu projekteihin, joista ei odoteta tuottoja/voittoja seuraaviin viiteen vuoteen?

7. Jos osakemarkkinat hinnoittelisivat yrityksenne pitkän aikavälin investointinne oikein kuinka paljon arviolta yrityksenne lisäisi investointeja?

8. Keskimääräinen takaisinmaksuaika- ja tuottovaatimus investoillenne on vuotta $\%$ (nimellinen tuottovaade) 


\section{The Questionnaire (translated)}

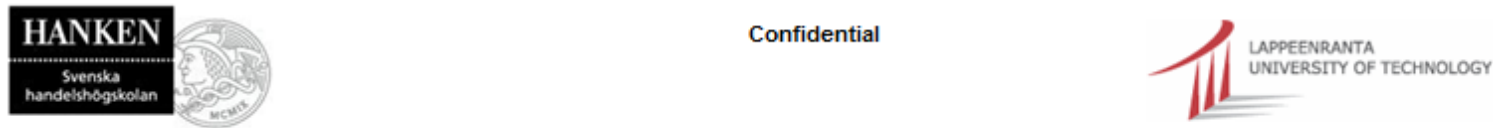

PROFIT! OR YOU'RE OUT! - ownership in quarterly economy research project

IOPINIONS

1. Have you felt that short-term expectations coming from outside the company for frequent improvements in the company's profitability has created a conflict with your company's long-term goals?

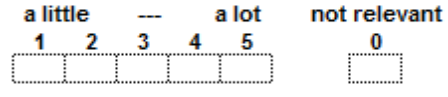

2. If yes, how much the following stakeholders have caused your company short-term pressure?
Media
Analysts
Politicians
Government-owner
Family owners
Finnish institutional owners
Finnish owners (other)
Foreign owners
Workers and their unions

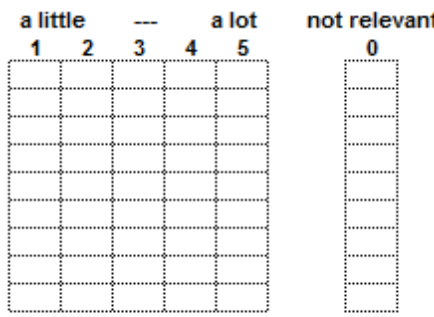

II PRACTICES

1. Has your company changed their activities / taken the short-term pressure into account when making decisions on ...
a. management compensation policy
b. dividend policy
c. capital structure
d. long-term investments
e. hiring / layoff decisions
f. R\&D-expenditures
g. financial reporting policy
h. CG
i. required rate of return / payback period
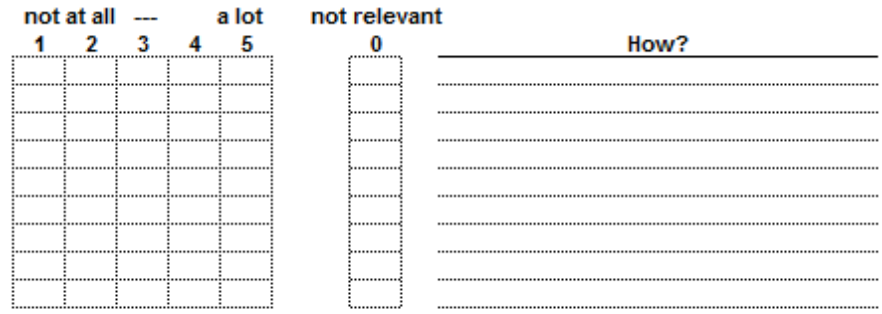

2. Largest weight in you top managements compensation plan is based on measures calculated over ...

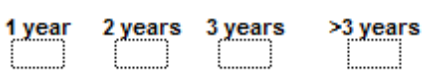

Additional explanation, if required

3. Put the following potential criteria in your top management's compensation plan in order of importance (1. = most important, etc.; empty = not used):
Profitability (ROI, ROCE etc.)
Profit (EBTDA, EPS etc.)
Stock price / market value

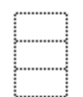

Growth

Operative cash flow

Other, what?

4. Has your company actively tried to influence the development of its ownership structure over long-term?

If yes or to some deqree, used methods:

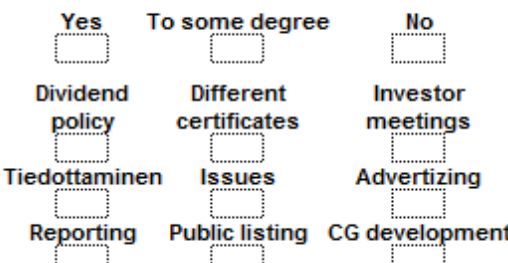

Other methods, what? 
5. Have you done share repurchases?

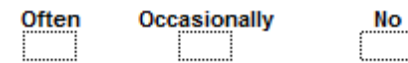

If often or occasionally, the main reasons are:

Wish of Stock under- To improve

foreign owners valued financial ratios

Wish of Development

Finnish owners Tax reasons of capital structure

Flexibility if Development

Other reasons, what?

Flexibility if
of ownership structur

$$
\text { compared to dividens of ownership structure }
$$

6. What proportion of your R\&D-expenditures is aimed at project from which you do not expect profit/income within the next five years? $\%$

7. If the stock market would value your long-term investments correctly, how much would you increase your investments?

8. Average payback and hurdle rate for your investments is years $\%$ (nominal)

If needed, please continue on the other side. 


\section{Forskningsrapporter från Svenska handelshögskolan \\ Swedish School of Economics and Business Administration. Research Reports.}

31. CARL-JOHAN ROSENBRÖIJER: The Changing Relationships and Strategic Identities of Actors in an Industrial Distribution Channel. A Study of Distribution Channels for A4 Paper in Finland. Helsingfors 1994.

32. JAMES G. MARCH: Three Lectures on Efficiency and Adaptiveness in Organizations. Helsingfors 1994.

33. STUDIA ECONOMICA. Bidrag med anledning av Svenska handelshögskolans doktorspromotion 25.11.1994. Vasa 1995.

34. CORPORATE SUCCESS FACTORS DURING TIMES OF CRISIS. Edited by Anders Kjellman, Stefan Långström and Tage Vest. Vasa 1996.

35. MARIKA TANDEFELT: På vinst och förlust. Om tvåspråkighet och språkförlust i Helsingforsregionen. Helsingfors 1996.

36. MARIA HOLMLUND: A Theoretical Framework of Perceived Quality in Business Relationships. Helsingfors 1996.

37. PETER BJÖRK: Ekoturism - en introduktion till ett helhetsperspektiv, med definitioner och empirisk forskning. Helsingfors 1997.

38. INGALILL ASPHOLM: Idkande av företagsverksamhet i Estland. En bolagsrättslig studie om de finskägda företagens erfarenheter av den rättsliga regleringen på den estniska marknaden. Helsingfors 1997.

39. MIKA VAIHEKOSKI: Essays on Conditional Asset Pricing Models and Predictability of Finnish Stock Returns. Helsingfors 1997.

40. HORST ALBACH: Global Competition Among the Few. Helsingfors 1997.

41. INGER ROOS: Customer Switching Behavior in Retailing. Helsingfors 1998.

42. CONSTRUCTING R\&D COLLABORATION: LESSONS FROM EUROPEAN EUREKA PROJECTS. Edited by Guje Sevón and Kristian Kreiner. Copenhagen 1998.

43. PIA POLSA: The Distribution of Consumer Goods in the People's Republic of China. An Empirical Study of Packaged Food Products. Helsingfors 1998.

44. PONTUS TROBERG and JANNE VIITANEN: The Audit Expectation Gap in Finland in an International Perspective. Helsingfors 1999. 
45. THOMAS SANDVALL: Essays on Mutual Fund Performance Evaluation. Helsingfors 1999.

46. ANDERS TALLBERG: An Economic Framework for Information Integrity. Helsingfors 1999.

47. KIRSTI LINDBERG-REPO: Word-of-Mouth Communication in the Hospitality Industry. Helsingfors 1999.

48. JOAKIM WESTERHOLM: Essays on Initial Public Offerings, Empirical Findings from the Helsinki Stock Exchange. Helsingfors 2000.

49. JUSSI HYÖTY: Yield Surrogates, Financial Variables and Expected Returns; Empirical Evidence from Finland. Helsingfors 2000.

50. THERESE LEINONEN och MARIKA TANDEFELT: Svenskan i Finland - ett språk i kläm? Unga finlandssvenskars modersmål. Helsingfors 2000.

51. HELI ARANTOLA: Buying Loyalty or Building Commitment? - An Empirical Study of Customer Loyalty Programs. Helsingfors 2000.

52. MIKA AALTONEN ja ANNE KOVALAINEN: Johtaminen sosiaalisena konstruktiona. Helsinki 2001.

53. MARIKA TANDEFELT: Finländsk tvåspråkighet. Helsingfors 2001.

54. BARRY EICHENGREEN: Global Financial Crisis Resolution: Issues and Options. Helsingfors 2002.

55. LAMA JA LUOTTAMUS. Toimittajat Kaj Ilmonen, Anne Kovalainen ja Martti Siisiäinen. Helsinki 2002.

56. PETRA SUND-NORRGÅRD: Domännamnstvister och ond tro. En rättslig analys av UDRP, särskilt med tanke på begreppet ond tro i artikel 4.a.iii. Helsingfors 2002.

57. JEFF HEARN, ANNE KOVALAINEN and TEEMU TALLBERG: Gender Divisions and Gender Policies in Top Finnish Corporations. Helsingfors 2002.

58. MARGIT BRECKLE und INGO HEYSE: Hur mycket IKT behöver en studerande? Virtuelle Kurskonzepte und ihre Auswirkung auf Leistung, Zufriedenheit und Arbeitsstrategien. Helsingfors 2003.

59. ALF-ERIK LERVIKS: Simulating and Forecasting the Demand for New Consumer Durables. Helsingfors 2004.

60. PÄIVI ERIKSSON et al. (toim./eds): Sukupuoli ja organisaatiot liikkeessä? Gender and Organisations in Flux? Helsinki 2004.

61. MARCUS NORRGÅRD: Avtalsingrepp. Om otillbörliga ingripanden i kommersiella avtalsförhållanden. Helsingfors 2006. 